\title{
Parametric Analysis on an Earth-to-Air Heat Exchanger Employed in an Air Conditioning System
}

\author{
Diana D'Agostino 1(D, Francesco Esposito ${ }^{1}$, Adriana Greco ${ }^{1, *}$, Claudia Masselli ${ }^{2}$ (D) \\ and Francesco Minichiello ${ }^{1}$ \\ 1 Department of Industrial Engineering, University of Naples Federico II, P.le Tecchio 80, 80125 Napoli, Italy; \\ diana.dagostino@unina.it (D.D.); france.esposito@gmail.com (F.E.); francesco.minichiello@unina.it (F.M.) \\ 2 Department of Industrial Engineering, University of Salerno, Via Giovanni Paolo II 132, 84084 Fisciano (SA), \\ Italy; cmasselli@unisa.it \\ * Correspondence: adriana.greco@unina.it; Tel.: +39-081-768-2289
}

Received: 12 May 2020; Accepted: 5 June 2020; Published: 7 June 2020

\begin{abstract}
This paper is focused on the resort to geothermal energy, through the employment of an Earth-to-Air-Heat Exchanger (EAHX) positioned upstream of the air-handling unit of an air conditioning system, for an office building in Naples (South Italy). The aim is to evaluate the energy performances of this unusual system compared to the common solution of external air directly entering the air-handling unit. The EAHX is extensively designed and two-dimensionally modeled, and the analysis is solved with finite element method. The model is validated with experimental data and this comparison shows good agreement. With the requirement of providing the building with $1300 \mathrm{~m}^{3} \mathrm{~h}^{-1}$ of external airflow, different design solutions for the EAHX are studied, by varying the diameter (in the range $0.2-0.5 \mathrm{~m}$ ) and length (between 20 and $140 \mathrm{~m}$ ) of the buried pipes. The results indicate that: smaller tube diameters enhance the heat transfer; a tube length between 80 and $100 \mathrm{~m}$ is recommended. Using the EAHX, the reduction of the thermal power of the coils in the air-handling unit is greater than $40 \%$ in most cases. Finally, the efficiency of the EAHX is assessed as a function of the tube length and diameter, reaching values up to 0.9 .
\end{abstract}

Keywords: geothermal energy; earth-to-air heat exchanger; numerical model; parametric study; energy recovery; air conditioning

\section{Introduction}

\subsection{Describing the Concepts}

The growing interest in finding alternative to refrigeration and Heating, Ventilation \& Air Conditioning (HVAC) systems based on vapor compression, has guided the scientific community in developing solutions based on renewable energies. Renewable energy refers to the supply of energy through renewable resources which are naturally produced faster than they are used. The most common are solar, wind, biomass, rain, tides, waves, and geothermal heat-based energies.

The systems exploiting geothermal energy take advantage of the temperature property of the ground to be constant after a certain depth. Indeed, they have the common denominator of use the ground to lessen the building cooling load in summer and heating load in winter. The soil becomes a heat source-sink for the heating and cooling of the built environment as well as for providing domestic hot water, with the result of preserving a certain amount of primary energy, thus lowering the environmental impact connected to polluting emissions, as summarized by Soni et al. [1] and Sarbu et al. [2] in their reviews.

Ground Source Heat Pumps (GSHPs) and Earth-to-Air Heat eXchangers (EAHXs) are among the most used ground coupled systems. GSHP systems are heat pumps that contemplate the circulation 
of the heat transfer fluid in a buried pipe exchanging heat with the ground, taking advantage of the fact that the undisturbed soil temperature is approximately constant and therefore is higher than the outside air in winter and lower in summer.

EAHX systems are heat exchanging systems formed by buried tubes. The heat transfer fluid is commonly air, which is blown inside the buried pipes to reach a temperature close to that of the ground: this pretreated air can be used to help meet cooling and heating needs of the building. Earth-to-air heat exchangers can be open/closed-loop based systems. In the open loop system, a continuous supply of external air is pumped inside the buried pipe where it is treated thanks to the interaction with the soil and no recirculation systems are envisaged. On the other side, in the closed loop the air flowing into the tube cyclically re-circulates into the system from the building to the EAHX and the other way around. An EAHX based system can be designed with both vertical and horizontal tubes, and the number of pipes could typically varies depending on different factors, such as the available installation space, the required volumetric airflow rate and thermodynamic optimization factors. The vertical-pipes EAHXs usually require higher installation and maintenance costs than the horizontal-pipes ones.

As a matter of fact, different factors influence the performances of the earth-to-air heat exchangers, such as: shape and diameters of the pipes, fluid velocity, burial depth and number of the pipes, intensity of the solar radiation, as well as the ground thermodynamic characteristics and the moisture content of the soil. The combinations of such factors could carry to optimize different aspects of the EAHX, like the soil-air heat exchange, trying to amortize its purchase and installation costs. The EAHX could be employed in many different applications: the more suitable concerns about it are inserting of this component inside the mechanical ventilation system or the air conditioning system. Indeed the EAHX could be identified as a pre-heating or pre-cooling component of the outside air to be introduced directly into the building, for energy saving purposes with respect to a simple system which not presents this geothermal component.

\subsection{State of the Art And Research Gap}

Scientists who assess the health of our planet see indisputable evidence that Earth has been getting warmer, in some cases rapidly. Most believe that human activities, in particular the burning of fossil fuels and the resulting build-up of greenhouse gases in the atmosphere, have influenced this warming trend [2-5]. The 21st century has witnessed a remarkable increase in the energy demand: the worldwide annual per capita energy consumption climbed from $1400 \mathrm{kWh}$ in 1975 to $3200 \mathrm{kWh}$ in our days, as documented by the World Bank Open Data [6]. This need for energy touches all the sectors [7]. Among the most crucial ones are the heating, cooling, and air conditioning fields, to which more than $20 \%$ of the total all-over the world energy consumption is attributed [8]. A drastic "change of course" is necessary, starting from mutating the concepts of energy sources and the way we conceive cooling and air conditioning. Brown et al. [9] in their perspective review underlined the main applications alternative to vapor compression technology for refrigeration and air conditioning up to 2012. Subsequently, Brown and Domanski explored alternative solutions to vapor-compression in the cooling field [10], whereas Goetzler et al. focused on air-conditioning technologies different from vapor compression [11].

In 2013, Rosiek and Batlles [12] proposed different solutions based on the use of renewable energy to supply a HVAC system of an institutional building located in Spain. Specifically, they investigated three possible solutions for implementing a HVAC system through renewable energy: (i) a solar absorption-based system; (ii) a solar-geothermal electric vapor compression system and (iii) a solar electric vapor compression based HVAC system. Moretti et al. [13] introduced two pilot systems to improve the energy saving in two non-residential buildings located in Umbria (Italy): in both the edifices photovoltaic plants were installed to supply electrical energy coming from renewable source. Furthermore, two different HVAC systems were installed: in a building the air conditioning is based on a geothermal heat pump; in the other one a biomass boiler is coupled with an absorption chiller 
machine. Pajak et al. [14] reviewed about the low enthalpy solutions for using geothermal energy to obtain energy saving in heating systems of Urban districts.

Geothermal energy has been exploited for electricity supply since 1913; for the next forty years the total amount of geothermal power intended for both electricity generation and direct use was on a scale of hundreds of MW. In the 1970s the geothermal energy demand grew fast and in the 2000s geothermal resources are exploited in more than 80 countries all over the world. Nowadays, the use of ground coupled systems exploiting geothermal energy is increased worldwide: they are mainly applied for air conditioning, domestic water heating, farming drying, etc. Indeed, the worldwide exploitation of geothermal energy amounts to $50 \mathrm{TWh} \mathrm{yr}^{-1}$ for electricity and $54 \mathrm{TWh} \mathrm{yr}^{-1}$ for direct supply, as summarized in the inherent reviews provided by Fridleifsson [15] and Tester et al. [16].

As asserted by Cadelano et al. [17], with reference to a case study relative to a museum, the use of geothermal sustainable systems can enhance the energy efficiency of HVAC plants together with improving the renewable energy source utilization without affecting the indoor environmental conditions. Trota et al. presented [18] an estimation of the geothermal power potential with reference to two sites located in Portugal, characterized by different geological and geodynamic settings, based on a Monte Carlo approach. As a result, they confirmed the well-known potentiality of geothermal energy both for a low and a high enthalpy geothermal soil.

All over the world scientists investigated the performances of Earth-to-Air Heat eXchangers by means of different numerical models or computational methods, in a wide number of distinguished scenarios: the results carried out are well summarized by Bordoloi e al. in their review [19], where all the main EAHX-based systems are classified and compared up to the year 2018. Furthermore, among the new works on the EAHX, particularly noteworthy is the parametric study of Zhao et al. introduced in 2019 [20], where a 1:20 scaled experimental model is created to study the influence of the different parameters on thermal performances (mainly, the tube length and diameter, and the inlet air velocity). The authors evaluated the temperature extraction efficiency $\eta$, defined as the outlet-inlet temperature span up to the difference between the soil and the inlet air. They detected that $\eta$ increases with augmenting the tube length, while it reduces following an increase in both the pipe diameter and the inlet air velocity. They reported that for a $20 \mathrm{~mm}$ pipe diameter, an increase of the air velocity from $0.5 \mathrm{~m} \mathrm{~s}^{-1}$ to $3 \mathrm{~m} \mathrm{~s}^{-1}$ carries to a $\eta$ decrement of 0.33 in summer and 0.13 in winter. Moreover, for this experiment the highest $\eta$ of 0.96 was detected for an air velocity of $0.5 \mathrm{~m} / \mathrm{s}$ and a pipe diameter of $20 \mathrm{~mm}$ in summer. The cooling and heating capacities were $21.17 \mathrm{~kW}$ and $21.72 \mathrm{~kW}$, respectively. Furthermore, they observed that the effect of the burial depth of the tube on the heat transfer is not easily predictable below $4 \mathrm{~m}$. In 2020, Lin et al. [21] studied the influence of the soil moisture on the long-term energy performances of an EAHX system at dry, partially and fully saturated conditions, through an analytical approach. The computational method was experimentally validated for a condition of a middle saturation. A very small impact of soil moisture content was detected in the air flows with low velocity but a strong difference among the three cases up to $40 \%$ between dry and fully saturated conditions on long-term energy performances of the system was appreciated, specifically if the air flux reaches the turbulent flow. Therefore, they prescribed that the maximum recommended air velocity should not be greater than $4.0 \mathrm{~m} \mathrm{~s}^{-1}$. Among the latest published works, in April 2020, Skotnicka-Siepsiak [22] introduced a comparison between numerical and experimental results related to a ground-to-air heat exchanger for a mechanical ventilation system in a building of Poland. The comparison was perpetuated continuously in the whole summer season and the author detected that the model was able to correctly predict the thermal performances of the ground-to-air heat exchanger only in some of the analyzed months. Anyhow, the experimental results revealed that during summer season, the system reached a total cooling saving of $115.6 \mathrm{kWh}$, where sensible cooling capacity accounted for $54 \%$ and latent cooling capacity for $46 \%$ of the overall energy balance. Among the conclusions the author also asserted that the cooling performance of an earth-to-air heat exchanger is also related to the relative humidity of the entering air and to moisture condensation. The latter observation found confirm in the work of Díaz-Hernández et al. [23], published in March 2020, where an experimental 
investigation on the thermal performances of an earth to air heat exchanger placed in warm humid climatic conditions was presented. Considering $27^{\circ} \mathrm{C}$ as ground temperature, the system worked as cooler during office daytime (from 9:00 to 18:00), with a maximum of temperature cooling gain of $5.5^{\circ} \mathrm{C}$ in January and an average of $2.8^{\circ} \mathrm{C}$ in August. Authors supposed that the characteristics of the warm humid climate and the ground allow to reduce the temperature of the airflow, but considering that the EAHX could be used as a cooler in places where activities are scheduled in a limited time during day, as for example in offices. Benrachi et al. [24] in 2020, introduced a numerical investigation on a novel EAHX supposed to be designed in spiral-shape specifically to be placed in hot and arid climate regions (Algeria). Through ANSYS FLUENT software, a three-dimensional model was developed, solved with the finite volume method and validated with experimental results published in open literature. In the parametric analysis the effects of the pipe pitch, depth and length, as well as airflow velocity, were analyzed. They detected that for a pitch space variation between 0.2 and $2 \mathrm{~m}$, inlet-outlet temperature span increases of $6^{\circ} \mathrm{C}$. An air velocity increment from 2 to $5 \mathrm{~m} \mathrm{~s}^{-1}$ carries to mean decrements of the efficiency from $60 \%$ to $33 \%$ and of the COP from 2.84 to 0.46 .

In addition to optimizing the heat exchange regarding the EAHX, another research topic concerned the more suitable inserting of this component inside the mechanical ventilation system or the air conditioning system. The most common applications of the earth-to-air heat exchanger identify it as a pre-heating or pre-cooling component of the outside air to be introduced directly into the building (by a mechanical ventilation system), so the energy savings related to the EAHX inserted upstream of a mechanical ventilation system were often evaluated by comparing this solution to a simple mechanical ventilation system without EAHX [25].

$\mathrm{Li}$ et al. [26] introduced an evaluation of the annual performances of a mechanical ventilation system provided with an EAHX and an air-to-air heat recovery unit (the two exchangers are in series) compared to a heat pump coupled to a primary air-handling unit. The analysis was conducted in severe cold regions, and energetic, economic and environmental aspects were evaluated. The authors detected that the innovative system carries a considerable economic and environmental benefit compared to the traditional solution. Specifically, the static and dynamic payback periods when using the system with the EAHX were about 2.1 and 2.4 years (return rate of $8 \%$ ); from the point of view of greenhouse gas emissions, there was a reduction of $17 \%$. In this article, the depth of two buried pipes was 2.5 and $5 \mathrm{~m}$ and a parametric analysis was carried out by spacing the pipes both at $2 \mathrm{~m}$ and at $5 \mathrm{~m}$, showing that the useful effect is greater the more the two pipes are distant.

Another strategy consists instead in inserting the EAHX in a hybrid air conditioning system $[1,19]$. However, the configuration with the EAHX upstream of the air handling unit (AHU) was rarely analyzed in the previous literature works [27-29].

Other studies investigated the benefits that EAHX brings to a building in relation to different climatic conditions $[27,30]$ or based on the type of soil [31] without specifying how this system was integrated into the HVAC system.

The performances of the earth-to-air heat exchanger were sometimes analyzed by comparing it with the air-to-air heat exchanger, highlighting also in this case significant energy savings against higher economic costs [28,29]. About this kind of comparison (between the EAHX and the air-to-air heat recovery), also the research results reported in [32,33] can be useful. Zeng et al. [32] showed that the air-to-air heat exchanger coupled to an AHU leads to considerable savings. Furthermore, Kalbasi et al. [33] demonstrated how by coupling an air-to-air heat exchanger to an AHU, the cooling power decreases between $27 \%$ and $36 \%$ and the total required power decreases up to $11 \%$.

\subsection{Contribution Provided by the Performed Investigation}

Considering the above introduced state of the art (specifically, the scientific community scenario on developing hybrid solutions of mechanical ventilation or air conditioning systems provided with EAHX), with our work we aim to fill the research gap. The main innovative elements proposed in this paper are the following: 
- the coupling of a double approach, i.e., the rigorous solution of the heat transfer problem related to the EAHX (through the development and experimental validation of a two-dimensional numerical model based on the finite elements method), and a more practical approach tending to evaluate the benefits obtaining for the air conditioning system;

- the positioning of the EAHX upstream of the AHU, which represents a system configuration rarely analyzed in the previous literature works [27-29]. In this way, the EAHX is not a simple pre-treatment of the air to be introduced into the building by means of a mechanical ventilation system, but a component inserted in the air conditioning system;

- the analysis of the power of the heating and cooling coils present in the air handling unit and the evaluation of the relevant reduction obtained for this power (with consequent significant decrease of the overall energy consumption).

As far as the authors are aware, these three aspects are not found in the available literature (in particular if considered all together), even in the previous works of the authors.

Specifically, in the present paper the results of an investigation conducted on a HVAC system for an office building, placed in the city of Naples (South Italy), are presented. Even if the study was conducted for the city of Naples, the interest toward this study is not limited for the local application but it concerns a broad international interest, since the results carried out can be extended to the entire C global climatic zone, according to Köppen climate classification [34]. Such classification identifies the locations belonging to this zone as characterized by mild temperate climates (monthly average temperature of the warmest month is equal or greater than $10^{\circ} \mathrm{C}$, monthly average temperature of the coldest month ranging from $-3{ }^{\circ} \mathrm{C}$ to $18^{\circ} \mathrm{C}$ ).

As introduced previously, the system analyzed is composed by an Air Handling Unit (AHU) for the primary air coupled with a horizontal-pipes EAHX and fan-coil units. The EAHX is constituted by five circular horizontal buried pipes (for air flowing) installed between $2 \mathrm{~m}$ and $2.5 \mathrm{~m}$ deep. The distance between two adjacent pipes is $2.5 \mathrm{~m}$, chosen to avoid the thermal interaction between the two elements. The model extensively two-dimensionally designed is constituted by one of the five circular horizontal buried pipes of the EAHX surrounded by a ground volume $20 \mathrm{~m}$ deep, and then the problem is solved with finite element method. The simulations on the EAHX are performed by varying the length and the diameter of the pipes; thus, also the air velocity is varied since the volumetric flow rate to be provided to the AHU must be kept constant. Once the outlet temperatures of the air at the exit of the buried tube have been assessed, the EAHX is thermodynamically connected with the AHU, i.e., the external air pre-heated or pre-cooled by the geothermal heat exchanger is not directly introduced into the building but it is sent to the AHU. Subsequently the energy performances of the above-mentioned HVAC system are analyzed, both in summer and in winter operation modes. Specifically, the reduction of the power of the heating and cooling coils in the AHU due to the pre-treatment of the air operated by the EAHX, the efficiency of the EAHX and the inlet-outlet temperature span are evaluated through a parametric analysis in which the length and diameter of the EAHX pipes are varied.

\subsection{Organization of the Paper}

In the following sections the paper is organized as follows:

- in Section 2 the case study is widely described, together with an accurate analysis of the HVAC system and of all the components in dual configuration: with and without the implementation of the EAHX;

- in Section 3 the methodology of the investigation and the developed two-dimensional model of the earth-to-air heat exchanger are reported;

- in Section 4, after demonstrating the validation of the model with experimental data, the energy performances of the EAHX in terms of outlet temperature and efficiency are obtained and presented. Furthermore, the power of heating and cooling coils present in the air handling unit and the percentage reduction deriving from the introduction of the EAHX upstream of this air handling unit are shown and discussed widely; 
- finally, in the last section, the main conclusions about the results collected are drawn.

\section{Case-Study}

The case study is an office building, reported in Figure 1, that has rectangular shape; it extends over two floors for a total area of $260 \mathrm{~m}^{2}$ and a volume of $910 \mathrm{~m}^{3}$. The building is located in the city of Naples (South Italy, Lat. $40^{\circ} 51^{\prime} 22.72^{\prime \prime}$ N; Long. $14^{\circ} 14^{\prime} 47.08^{\prime \prime}$ E).

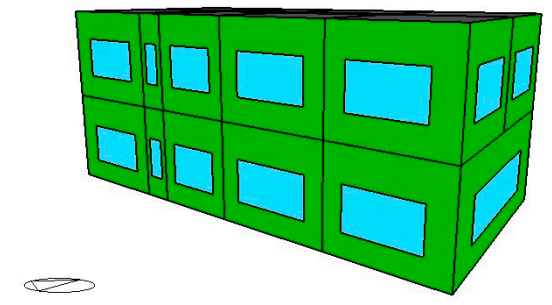

Figure 1. Tridimensional model of the office building.

The HVAC system is based on a condensing boiler coupled to an electrical air-cooled chiller. These components are responsible for producing hot and cold water connected to an air handling unit (for primary air treatment) and fan-coil units located in each room of the building. The design thermo-hygrometric conditions to be guaranteed inside each room are:

- indoor air: temperature of $20^{\circ} \mathrm{C}$ for winter and $26{ }^{\circ} \mathrm{C}$ for summer, relative humidity of $50 \%$ for

both winter and summer;

- $\quad$ supply primary air: temperature of $20^{\circ} \mathrm{C}$ for winter and $15^{\circ} \mathrm{C}$ for summer.

The design external airflow to be conveyed in the AHU of the building is $1300 \mathrm{~m}^{3} \mathrm{~h}^{-1}$ (11 $\mathrm{dm}^{3} /$ person) based on UNI 10,339 [35]. In this paper, two HVAC system configurations are proposed for the analyzed building (Figure 2). The first one is the common solution (without EAHX) in which the air, introduced into the AHU, is directly the external air. The second configuration consists in sending the pre-heated or pre-cooled air from the EAHX to the AHU.

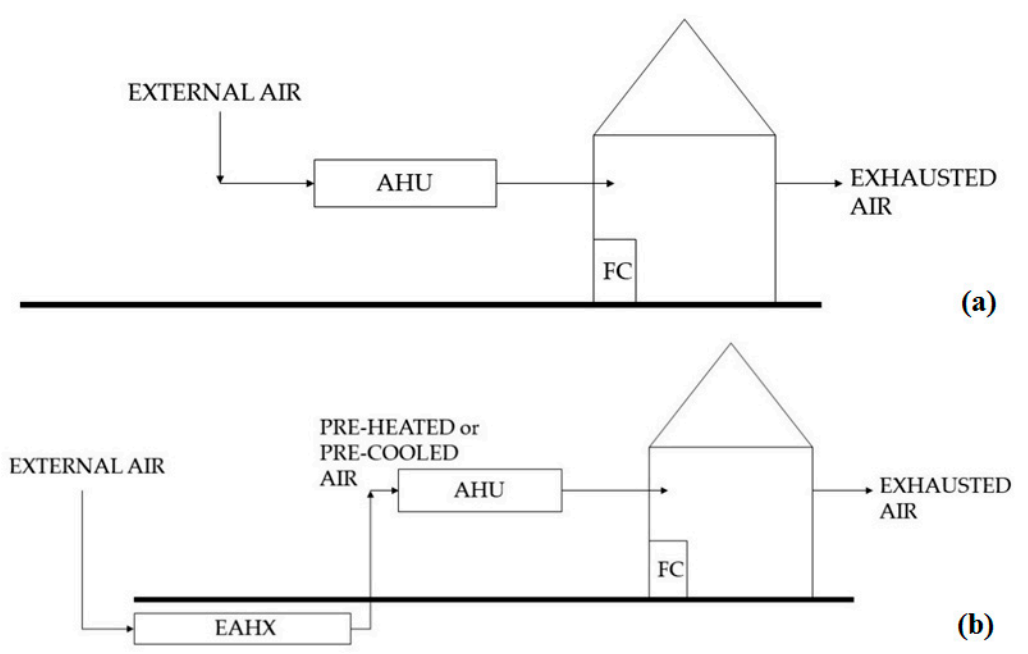

Figure 2. (a) HVAC system without EAHX. (b) HVAC system with EAHX.

As for the air handling unit, the system is composed of the following main elements:

- filters;

- $\quad$ pre-heating water coil;

- $\quad$ cooling and dehumidifying water coil; 
- humidifying section;

- re-heating coil;

- supply fan.

The capacity of the coils is assessed by means of mass and energy balances on the control volumes coinciding with the volume of the batteries. As schematized in Figure 3, during the summer season the components of the HVAC system that are in operation are the cooling coil and the re-heating coil, whereas during winter the active components are the heating coil, the humidifier with liquid water and the re-heating coil.

With reference to the summer season, as shown in Figure $4 \mathrm{a}$, the processes that the humid air undergoes are cooling and dehumidification $(\phi=100 \%)$ from point e (external air conditions) to point $A$ and subsequent re-heating from point $A$ to point i (supply or introduction conditions). During winter, as clearly visible in Figure $4 \mathrm{~b}$, the processes of humid air are pre-heating from point $e$ to point $A$, humidification with liquid water from point $A$ to point $B$ and post-heating from point $B$ to point $i$.

It should be noted that although the processes of the humid air inside the AHU are considered ideal (by-pass factor of the cooling coil equal to 0 and saturation efficiency of the humidifier equal to $100 \%$ ), the variations that more realistic air processes would entail on the coils' power (reported successively) are negligible.

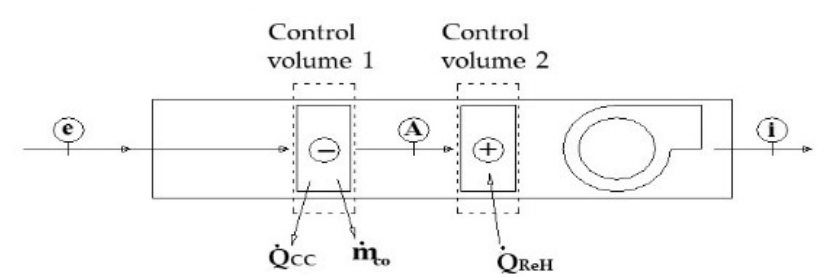

a

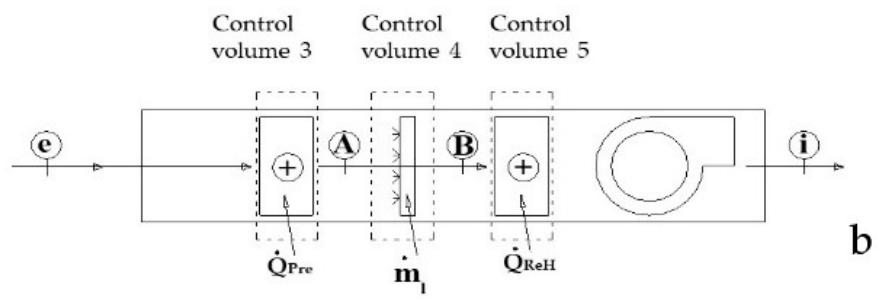

Figure 3. Scheme of the air handling unit for primary air and its components active in (a) summer and in (b) winter.

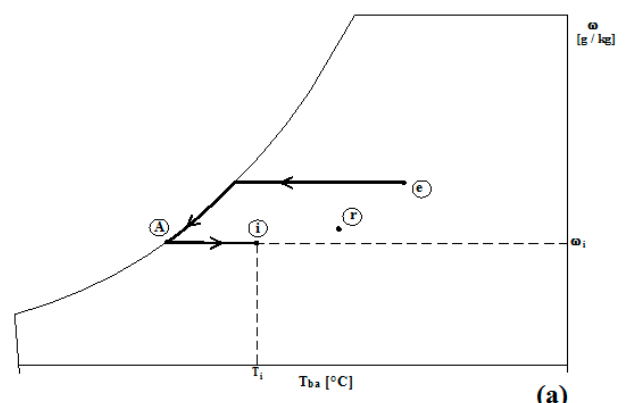

(a)

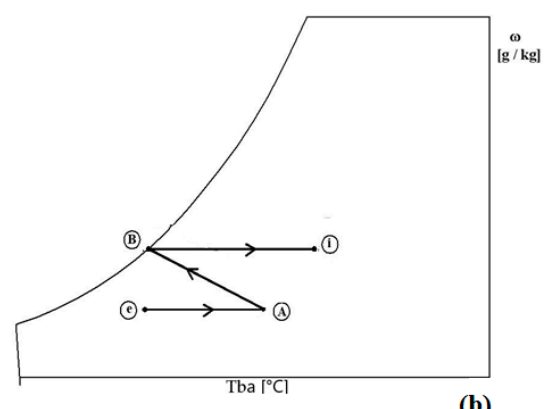

(b)

Figure 4. Processes of the humid air on the psychometric chart into the AHU during: (a) summer and (b) winter.

Below are reported the energy balance equations for calculating coil power when AHU operates in cooling mode (summer). The cooling coil power (control volume 1 of Figure 3) is calculated by means of Equation (1):

$$
\dot{Q}_{C C}=\dot{m}\left(h_{e}-h_{A}\right)-\dot{m}_{c o} h_{c o}
$$


The re-heating coil power (control volume 2 of Figure 3) is calculated by means of Equation (2):

$$
\dot{Q}_{R e H} \sim \dot{m} c_{p}\left(T_{i}-T_{A}\right)
$$

Below are the balance equations for calculating coil power when AHU acts in heating mode (winter). The pre-heating coil power (control volume 3 of Figure 3) is calculated by means of Equation (3):

$$
\dot{Q}_{P R E} \sim \dot{m} c_{p}\left(T_{A}-T_{e}\right)
$$

The mass flowrate of humidification water (control volume 4 of Figure 3)) is calculated by means of Equation (4):

$$
\dot{m}_{w}=\dot{m}\left(\omega_{B}-\omega_{A}\right)
$$

The re-heating coil power (control volume 5 of Figure 3) is calculated by means of Equation (5):

$$
\dot{Q}_{R e H} \sim \dot{m} c_{p}\left(T_{i}-T_{B}\right),
$$

In the configuration of the HVAC system with EAHX (Figure $2 b$ ), the point " $e$ ", which in the psychometric diagrams of the Figure 4 represents the design thermo-hygrometric conditions of the external air, is replaced with a new point characterized by the temperature of the air exiting from the EAHX, evaluated through the numerical simulations based on a developed numerical two-dimensional model solved with the finite element method.

Once the thermo-hygrometric conditions of this new point are obtained, the reduced power of the AHU coils are calculated both for summer and winter in the configuration with EAHX. Subsequently, the reduction of the coils' power resulting from the introduction of the EAHX compared to the usual AHU without EAHX is evaluated. The reduction in coils' power is assessed considering both each coil separately (pre-heating coil in winter and cooling coil in summer) and the total power of these coils (total power reduction taking into account summer + winter operation).

\section{Model Description of the EAHX and Methodology of the Investigation}

To evaluate the influence of the earth-to-air heat exchanger, it was extensively designed and modeled two-dimensionally and then the analysis was solved with finite element method. The EAHX with horizontal-pipes has been chosen as the vertical-pipes EAHXs usually require higher installation and maintenance costs.

\subsection{Model Design}

The computational domain of the model is constituted by one of the five circular horizontal buried pipes (for air flowing) of the EAHX surrounded by a ground volume $20 \mathrm{~m}$ deep. According to literature studies [36,37], this value was chosen to ensure at this deepness the ground is not affected by the presence of the pipes, thus resulting undisturbed. The pipes are in PVC with a thermal conductivity equal to $0.16 \mathrm{~W} / \mathrm{mK}$. The distance $d$ between two adjacent pipes is $2.5 \mathrm{~m}$, chosen to avoid the thermal interaction between the two elements.

As shown in Figure 5, a horizontally oriented buried pipe is installed between $2 \mathrm{~m}$ and $2.5 \mathrm{~m}$ in the soil because, in agreement with other investigations [38], at depths of more than $2 \mathrm{~m}$ below the surface, the soil temperatures are almost constant and close to the annual mean values of the external air. Clearly although the yearly temperature excursion decreases with the depth, on the other hand the excavation costs increase. Therefore, interring the pipe between $2 \mathrm{~m}$ and $3 \mathrm{~m}$ is a good compromise $[39,40]$. The pipe has a diameter $D$ and a length $L$. The modeled EAHX is open-loop, therefore the air entering the tube, with a velocity vector $\vec{v}$, has temperature and relative humidity proper of the external air. Since the model is solved with finite element method, in the figure is shown also the computational mesh whose shape is triangular. 


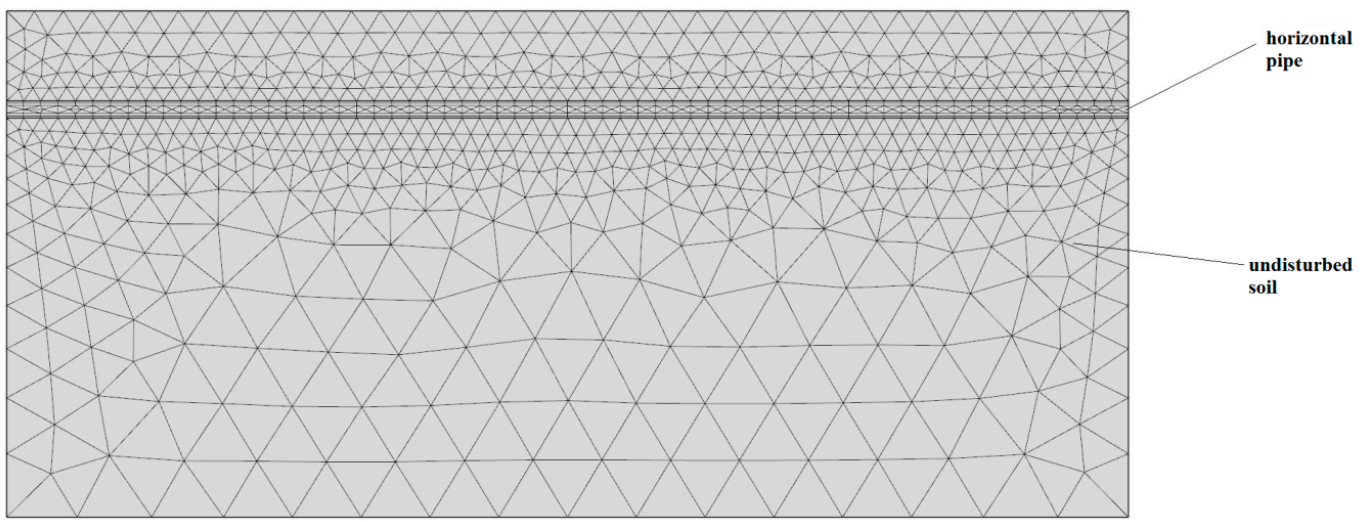

Figure 5. Computational mesh domain of the investigation on a single buried pipe of the EAHX.

\subsection{Mathematical Model}

The domain described in Section 3.1 is the domain regulated by the set of the equations characterizing the mathematical model. The following assumptions were made:

- the domain is two-dimensional;

- only one pipe of the EAHX was designed (since it was assumed to extend the overall results to the five pipes);

- a longitudinal section of the domain (composed by the ground and the pipe in which the air flows) was modeled since a symmetrical approach was considered;

- the fluid flows with velocity values ensuring the full turbulent motion;

- the air entering the model is humid air. Indeed, the model is able to provide punctually the typical parameters characterizing a humid air flow (dry and wet bulb temperature; relative and specific humidity) and the flow rate of the water eventually condensed;

- the study is time-dependent and the model was run until reaching the steady-state;

- the model is solved with finite element method: indeed the domain was divided in 70,625 triangular-shape elements; as visible from Figure 5, a higher concentration of elements is imposed inside and surrounding the pipe to represent more accurately the fluid domain and to evaluate precisely the temperature in the surrounding soil;

- the final mesh adopted for the simulation was chosen with a fitting factor guaranteeing the accuracy of the results with $\mathrm{a} \pm 0.01{ }^{\circ} \mathrm{C}$ spatial convergence error;

The study aims to investigate the conjugate heat transfer between solid (soil) and fluid (humid air). Therefore, the equations governing the domain are reported below:

- The mass conservation of the fluid is based on the Equation (6):

$$
\frac{\partial \rho}{\partial t}+\nabla(\rho \vec{v})=\dot{S}_{m}
$$

where $\dot{S}_{m}$ is the mass added or removed.

- The conservation momentum of the fluid is guaranteed by the Navier-Stokes equations for turbulent flow and is based on the Equation (7):

$$
\rho \frac{\partial \vec{v}}{\partial t}+\rho(\overrightarrow{\boldsymbol{v}} \cdot \nabla) \overrightarrow{\boldsymbol{v}}=\nabla \cdot\left[-p \overrightarrow{\boldsymbol{I}}+\left(\mu+\mu_{T}\right)\left[\nabla \overrightarrow{\boldsymbol{v}}+(\nabla \overrightarrow{\boldsymbol{v}})^{T}\right]\right],
$$

where $\mu_{T}$ is the turbulent viscosity modeled as reported in Equation (8):

$$
\mu_{T}=\rho C_{\mu} \frac{K}{\hat{\varepsilon}}
$$


with $C_{\mu}=0.09$, that is one of the constants of the $K-\hat{\varepsilon}$ model for turbulent flow [41].

- The energy equation is solved through the entire domain. For the fluid, the relation reported in Equation (9) is considered:

$$
\frac{\partial(\rho E)}{\partial t}+\nabla \cdot[\overrightarrow{\boldsymbol{v}}(\rho E+p)]=\nabla \cdot\left[k_{e f f} \nabla \mathrm{T}-\sum_{\mathrm{j}} \mathrm{h}_{\mathrm{j}} \mathrm{J} \rightarrow_{\mathrm{j}}+\left(\tau_{\mathrm{eff}} \cdot \overrightarrow{\boldsymbol{v}}\right)\right],
$$

where $k_{\text {eff }}$ is the effective conductivity defined as the sum of the conventional thermal conductivity of the fluid $\left(k_{f}\right)$ and the thermal conductivity of the turbulent flow $\left(k_{T}\right)$ and thus modeled as reported in Equation (10):

$$
k_{e f f}=k_{f}+k_{T}
$$

The soil domain is treated as virtual solid, indeed without considering any fluid flowing through porous media. On the other hand, the porosity was taken into account since, assuming a certain porosity value, the soil properties were weighted balanced according to the solid and the liquid property values as reported in Equation (11):

$$
z_{\text {soil }}=\psi z_{\text {liquid }}+(1-\psi) z_{\text {solid }}
$$

- Indeed, the energy equation solved in the soil domain becomes as reported in Equation (12):

$$
\frac{\partial\left(\rho_{\text {soil }} C_{\text {soil }} T_{\text {soil }}\right)}{\partial t}=\nabla \cdot\left(k_{\text {soil }} \nabla T_{\text {soil }}\right)
$$

The associated thermal boundary conditions are:

- at the side edges of the soil domain, a symmetry (2nd type) condition was imposed to model the presence of the ground laterally even beyond the domain;

- at the bottom of the soil domain, a 1st type condition was forced, following the undisturbed temperature of the ground identified through the Kusuda [42] relation, reported in Equation (13):

$$
T_{g}(y, t)=T_{m}-A \cdot \exp \left[-y \cdot \sqrt{\frac{\pi}{365 \cdot \alpha_{g}}}\right] \cdot \cos \left[\frac{2 \pi}{365} \cdot\left(t-t_{T_{\min }}-\frac{y}{2} \cdot \sqrt{\frac{365}{\pi \cdot \alpha_{g}}}\right)\right],
$$

- at the top of the soil domain (the surface), a 1st type boundary condition is considered. The sun-air temperature, that accounts both the incident radiation on the ground surface and the convective heat exchange with the external air, is imposed as reported in Equation (14):

$$
T_{s a}(x, 0, t)=T_{a i r, e x t}(t)+\frac{\alpha G(t)}{h_{c}},
$$

The air flowing into the pipe enters with the typical design parameters $(T, \Phi)$ of the city of Naples (Lat. $40^{\circ} 51^{\prime} 22.72^{\prime \prime} \mathrm{N}$; Long. $14^{\circ} 14^{\prime} 47.08^{\prime \prime} \mathrm{E}$ ). The weather data of Naples considered in the present investigation were identified through ASHRAE climatic data [43]. Naples is characterized by mild winters and hot summers, and thus belonging to the climatic zone $\mathrm{C}$, according to the Italian DPR 412/93 [44] that divides Italy in 6 different climatic zones with reference to winter. In Table 1 the design parameters of the city of Naples that were used for testing the air entering the EAHX are reported [43]. The value adopted for the convective heat transfer coefficient is $\mathrm{h}_{\mathrm{c}}=15 \mathrm{~W} \mathrm{~m}^{-2} \mathrm{~K}^{-1}$, according to the average weather conditions in terms of wind and $\Delta \mathrm{T}$ (between external air and soil surface), typical of South Italy [38]. 
Table 1. Winter and summer external design parameters for Naples [43].

\begin{tabular}{cccccc}
\hline City & Climatic Zone & $\begin{array}{c}\text { Heating } \\
\text { Degree Days }\end{array}$ & Latitude & Longitude & $\begin{array}{c}\text { Height above } \\
\text { Sea Level }(\mathrm{m})\end{array}$ \\
\hline Naples & $\mathrm{C}$ & 1134 & $40^{\circ} 51^{\prime} 22.72^{\prime \prime} \mathrm{N}$ & $14^{\circ} 14^{\prime} 47.08^{\prime \prime}$ E & 17 \\
\hline \multicolumn{2}{c}{ WINTER DESIGN PARAMETERS } & \multicolumn{2}{c}{ SUMMER DESIGN PARAMETERS } \\
\hline $\begin{array}{c}\text { Temperature } \\
\left({ }^{\circ} \mathrm{C}\right)\end{array}$ & $\begin{array}{c}\text { Relative } \\
\text { Humidity } \\
(\%)\end{array}$ & $\begin{array}{c}\text { Solar } \\
\text { Irradiation } \\
\left(\mathrm{W} / \mathrm{m}^{2}\right)\end{array}$ & $\begin{array}{c}\text { Temperature } \\
\left({ }^{\circ} \mathrm{C}\right)\end{array}$ & $\begin{array}{c}\text { Relative } \\
\text { Humidity } \\
(\%)\end{array}$ & $\begin{array}{c}\text { Solar } \\
\text { Irradiation } \\
\left(\mathrm{W} / \mathrm{m}^{2}\right)\end{array}$ \\
\hline 1,9 & 52 & 808 & 31.9 & 48.6 & 825 \\
\hline
\end{tabular}

According with the data provided on the Italian soils [45], the soil is composed by a solid and a liquid part. The solid part is a mixture of unconsolidated materials: clay, dry and wet slit, dry and wet gravel, dry and wet sand, peat and Morainic deposit. Indeed, following the VDI 4640-1 [46] the solid thermal properties listed in Table 2 (I column) are the resulting of the properties of the single above-mentioned elements, opportunely balanced. Therefore, we considered a medium conductivity soil for the solid part and we assumed a porosity of 37\%. The liquid part properties are the water ones at room temperature. Indeed, in Table 2 are summarized the soil properties obtained by a balanced combination of the solid and liquid (water) contributions [47], following Equation (11).

The temperature of the undisturbed soil is evaluated as mentioned in the previous paragraph through the equation of Kusuda [42] and for this evaluation the weather data of Naples identified through ASHRAE climatic data [43], and listed in Table 3, were used.

Table 2. Thermal properties of the soil.

\begin{tabular}{cccc}
\hline & Solid & Liquid & Soil \\
\hline $\mathrm{k}\left(\mathrm{W} \mathrm{m}^{-1} \mathrm{~K}^{-1}\right)$ & 2.20 & 0.65 & 1.63 \\
$\rho\left(\mathrm{kg} \mathrm{m}^{-3}\right)$ & 2500 & 1000 & 1700 \\
$\mathrm{c}_{\mathrm{p}}\left(\mathrm{J} \mathrm{kg}^{-1} \mathrm{~K}^{-1}\right)$ & 900 & 4200 & 1600 \\
\hline
\end{tabular}

Table 3. Temperature of the soil $\mathrm{T}_{\mathrm{g}}$ obtained by Kusuda equation for Naples.

\begin{tabular}{cccccccc}
\hline Climatic Zone/city & $\mathrm{T}_{\mathbf{m}}\left({ }^{\circ} \mathrm{C}\right)$ & $\mathbf{A}\left({ }^{\circ} \mathrm{C}\right)$ & $\mathbf{Y}(\mathbf{m})$ & $\alpha_{g}\left(\mathbf{m}^{2} /\right.$ day $)$ & $\mathbf{t}(-)$ & $\mathbf{t}_{\operatorname{Tmin}}(-)$ & $\mathbf{T}_{\text {ground }}\left({ }^{\circ} \mathrm{C}\right)$ \\
\hline C/Naples & 17 & 8.5 & 100 & 0.0821 & 365 & 15 & 17.00 \\
\hline
\end{tabular}

The EAHX under test is formed by five horizontal pipes, placed in parallel. The choice of dividing the total mass flow rate into five underground pipes was made to obtain air speeds around $2-2.5 \mathrm{~m} \mathrm{~s}^{-1}$ even for the smallest diameter $\left(\mathrm{D}=0.2 \mathrm{~m}\right.$ ). In fact, air speeds between $0.4-2.3 \mathrm{~m} \mathrm{~s}^{-1}$ allow a good compromise between heat exchange effectiveness and pressure drops [38]. A number of pipes lower than 5 would have resulted in an air speed higher than the optimal values in the case of $0.2 \mathrm{~m}$ in diameter. Furthermore, five pipes represent the maximum design limit in the case examined, given the space available for the installation of the EAHX. The air mass flow rate entering each pipe is calculated by means of Equation (15):

$$
\dot{m}_{\text {pipe }}=\frac{\dot{m}}{5}
$$

The investigation was performed for different lengths and diameters of the EAHX pipes, as reported in Equations (16) and (17):

$$
\begin{gathered}
L=[20 ; 50 ; 60 ; 80 ; 100 ; 120 ; 140 ; 160] m, \\
D=[0.2 ; 0.3 ; 0.5] m,
\end{gathered}
$$

Consequently, since the required volumetric flow rate to be conveyed in the building is $1300 \mathrm{~m}^{3} / \mathrm{h}$, the total air mass flow rate $\dot{m}$ at the EAHX inlet should remain constant. 
Indeed, given the relation reported in Equation (18):

$$
\dot{m}_{\text {pipe }}=\rho u S \text {, }
$$

where $S$ is reported in Equation (19):

$$
S=\pi \frac{D^{2}}{4}
$$

To keep the $\dot{m}_{\text {pipe }}$ constant, the air inlet velocity was varied according to the magnitude of the tube diameter under test. To ensure the model working with a turbulent flow, the Reynolds number defined as reported in Equation (20):

$$
\operatorname{Re}=\frac{u D}{v}
$$

was calculated for each diameter (and consequently inlet velocity) investigated and the obtained values are listed in Table 4, having considered the air properties referred to the inlet temperature.

Table 4. Reynolds numbers evaluated for each couple of diameter and inlet velocity considered.

\begin{tabular}{ccc}
\hline $\mathbf{D}[\mathbf{m}]$ & $\mathbf{u}[\mathbf{m} / \mathbf{s}]$ & $\operatorname{Re}\left[\mathbf{1 0}^{\mathbf{4}}\right]$ \\
\hline 0.2 & 2.3 & 2.83 \\
0.3 & 1.0 & 1.85 \\
0.5 & 0.37 & 1.14 \\
\hline
\end{tabular}

The efficiency of the EAHX could be evaluated as the difference of the temperature of the air exiting and entering the EAHX on the maximum useful temperature span, as reported in Equation (21):

$$
\varepsilon=\frac{T_{\text {outlet }}-T_{\text {inlet }}}{T_{\text {ground }}-T_{\text {inlet }}},
$$

\section{Results and Discussion}

The energy performances of the system where the EAHX pre-treating unit is coupled to AHU compared to the system without EAHX were evaluated for Naples. Consequently, the EAHX was tested, both for winter and summer, with the external air entering the pipe according to the design parameters (temperature, relative humidity) listed in Table 1.

As introduced in Section 3, the simulations on the EAHX were performed by varying the diameter and the length of the pipes.

Each test was performed in transient mode and the duration of each simulation was chosen according to let the EAHX reaching the steady state operation mode. Once the latter condition was reached, the outlet air temperature, efficiency of the EAHX, reduction of the power of the heating and cooling coils in the AHU due to the pre-treatment of the air operated by the EAHX were evaluated both in winter and summer season.

Preliminary, in order to check the reliability of the model, a comparison with experimental data available from the literature has been carried out.

\subsection{Validation of the Model with Experimental Data}

To ensure the affordability of the results obtained from the investigation, the model was validated with experimental data available in the open literature. Specifically we compared the results with the experimental data published by Hatraf et al. [48] and related to an Earth-to-Air Heat Exchanger assembled at the University of Biskra (Longitude $5^{\circ} 44^{\prime}$ east, Latitude $34^{\circ} 48^{\prime}$ north), characterized by a warm and dry summer, typical of Saharan climate. The experimental EAHX is constituted of four horizontal pipes buried $3 \mathrm{~m}$ deep: each pipe is $60 \mathrm{~m}$ length and presents a diameter of $0.11 \mathrm{~m}$. The system was tested with the external air entering the pipe at $36^{\circ} \mathrm{C}$; two different volumetric flow rates were considered flowing in each pipe $\left(135 \mathrm{~m}^{3} \mathrm{~h}^{-1}\right.$ and $\left.155 \mathrm{~m}^{3} \mathrm{~h}^{-1}\right)$. The Reynolds numbers 
corresponding to these flow rates $\left(2.6310^{4}\right.$ and $3.0310^{4}$, respectively) ensure that the air flowing could be treated as full turbulent.

Figure 6 shows a comparison between the experimental results published by Hatraf et al. [48] and the results carried out by the model introduced in this paper, considering the same geometrical, thermodynamical and boundary conditions of the experimental system. The comparison was carried out considering the inlet volumetric flow rates of $135 \mathrm{~m}^{3} \mathrm{~h}^{-1}$ (Figure 6a) and $155 \mathrm{~m}^{3} \mathrm{~h}^{-1}$ (Figure 6b). The comparison reveals that the medium error values are $1.6 \%$ and $1.5 \%$ for the volumetric flow rates of $135 \mathrm{~m}^{3} \mathrm{~h}^{-1}$ and $155 \mathrm{~m}^{3} \mathrm{~h}^{-1}$, respectively, whereas the maximum error values are $3.4 \%$ and $3.5 \%$. The accordance between experimental and numerical results could be considered acceptable.
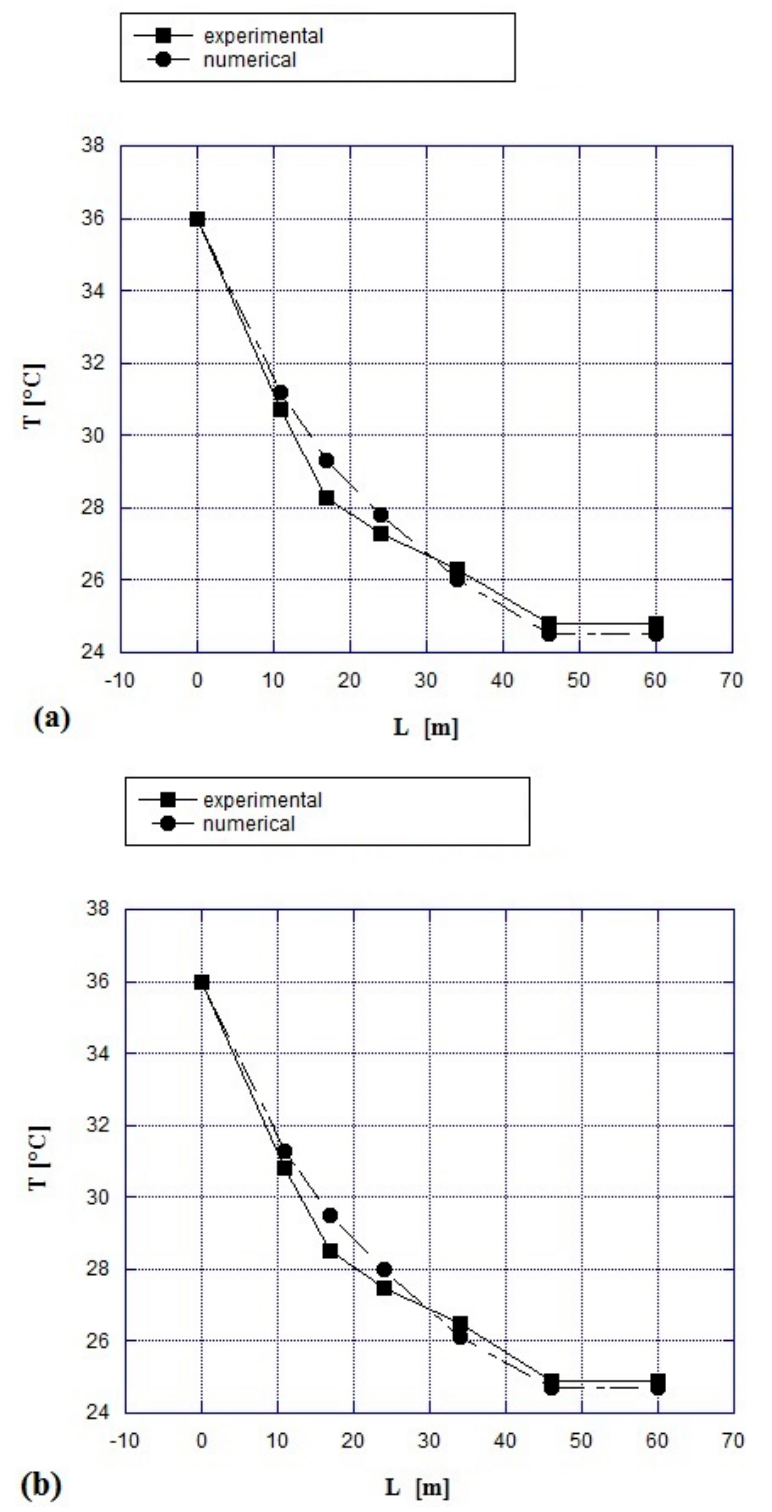

Figure 6. Experimental and numerical results for temperature of the air alongside one pipe of the earth-to-air heat exchanger with the inlet volumetric flow rates of $135 \mathrm{~m}^{3} \mathrm{~h}^{-1}$ (a) and $155 \mathrm{~m}^{3} \mathrm{~h}^{-1}$ (b).

Furthermore the EAHX model introduced in this paper was also validated with the experimental results published by Khabbaz et al. [49], related to an Earth-to-Air Heat Exchanger system located in Marrakech (Morocco; Latitude $31^{\circ} 38^{\prime} 02^{\prime \prime} \mathrm{N}$, Longitude $-7^{\circ} 59^{\prime} 59^{\prime \prime} \mathrm{E}$ ), a location characterized by a hot semi-arid climate.

As Khabbaz et al. report [49], their earth-to-air heat exchanger is composed by three horizontal parallel pipes (length: $72 \mathrm{~m}$; inner diameter: $15 \mathrm{~cm}$ ), buried between 2.2 and $3.2 \mathrm{~m}$ depth; the air enters 
the pipes with a velocity of $5 \mathrm{~m} \mathrm{~s}^{-1}$. We compared their experimental results with our numerical model, with the air characterized by two different inlet temperatures: $34.9^{\circ} \mathrm{C}$ and $35.9^{\circ} \mathrm{C}$. The corresponding Reynolds number $\left(4.55 \times 10^{4}\right)$ ensures that the air flowing could be treated as full turbulent. Therefore, our model was run, based on the turbulent model approach introduced in Equations (6), (7), (9) and (12), considering the same geometrical, thermodynamic and boundary conditions of the experimental system. In Figure 7 the results of the comparison between numerical and experimental results [49] are reported, considering the air inlet temperature of $34.9{ }^{\circ} \mathrm{C}$ (Figure 7a) and $35.9{ }^{\circ} \mathrm{C}$ (Figure 7b). The comparison reveals that the medium error values are, respectively, $0.59 \%$ and $0.56 \%$ for the test with the inlet temperature of $34.9^{\circ} \mathrm{C}$ and $35.9{ }^{\circ} \mathrm{C}$, whereas the maximum error values are $1.2 \%$ and $1.1 \%$. Indeed, there is good agreement between experimental and numerical results, also in this case.

The good agreement with the experimental results obtained in different climatic zones (the Saharan climate of Biskra and the climate of Marrakech) ensures that the model presented is suitable for operation in various climatic zones with acceptable results. Therefore, the analysis reported in this paper can be extended to other countries.
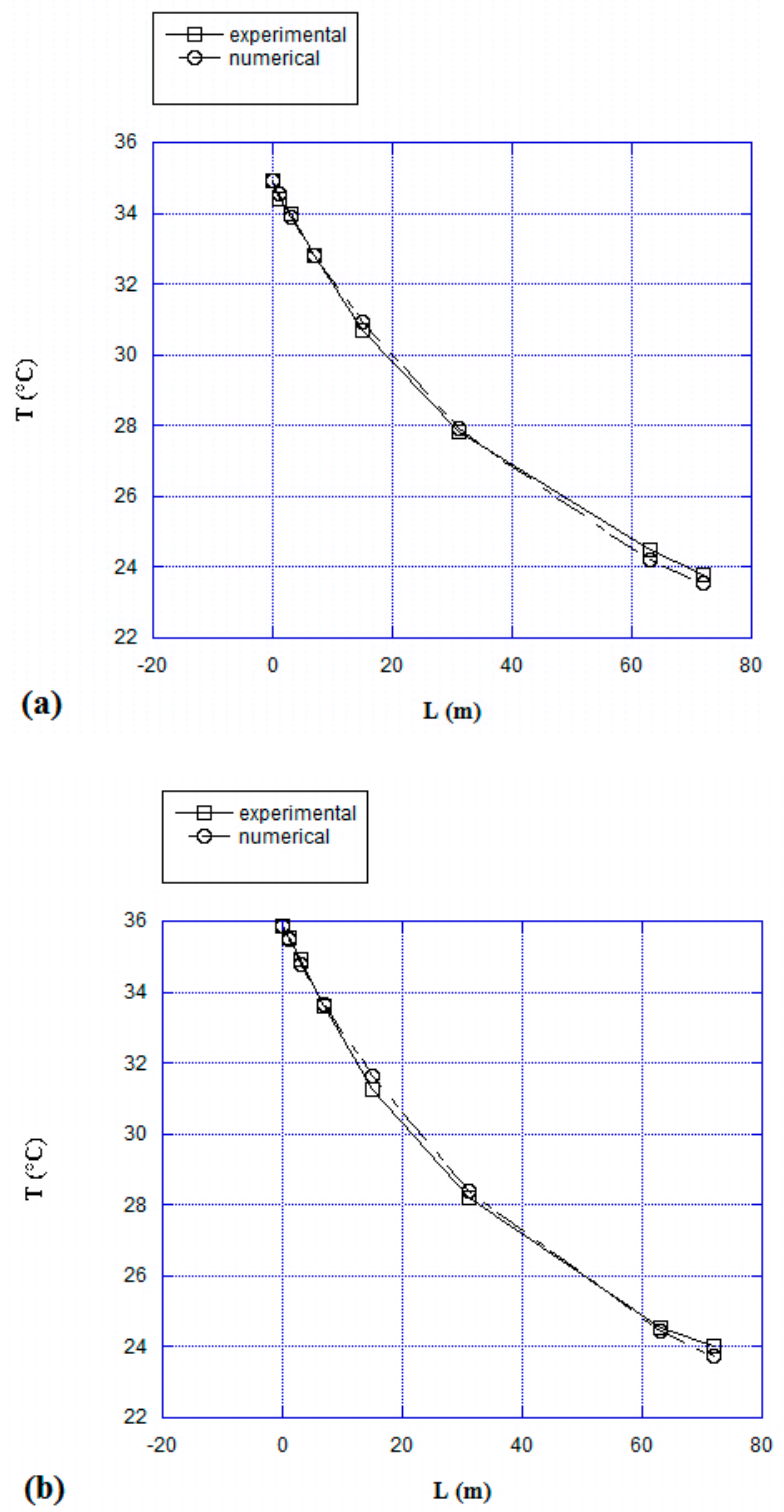

Figure 7. Experimental [49] and numerical results for temperature of the air flowing alongside one pipe of the EAHX at $5 \mathrm{~m} \mathrm{~s}^{-1}$ and inlet temperature of (a) $34.9^{\circ} \mathrm{C}$ and (b) $35.9^{\circ} \mathrm{C}$. 


\subsection{Thermal Performances of the EAHX}

The air temperature on the outside of the EAHX as a function of the tube length for the different inner tube diameters in both summer and winter season is reported in Figure 8, which clearly shows that the heat exchange is very pronounced up to $80 \mathrm{~m}$ : for longer lengths, air temperature gradually approaches an asymptotic value. Similar results were found by Chiesa [31] and Ascione et al. [40].

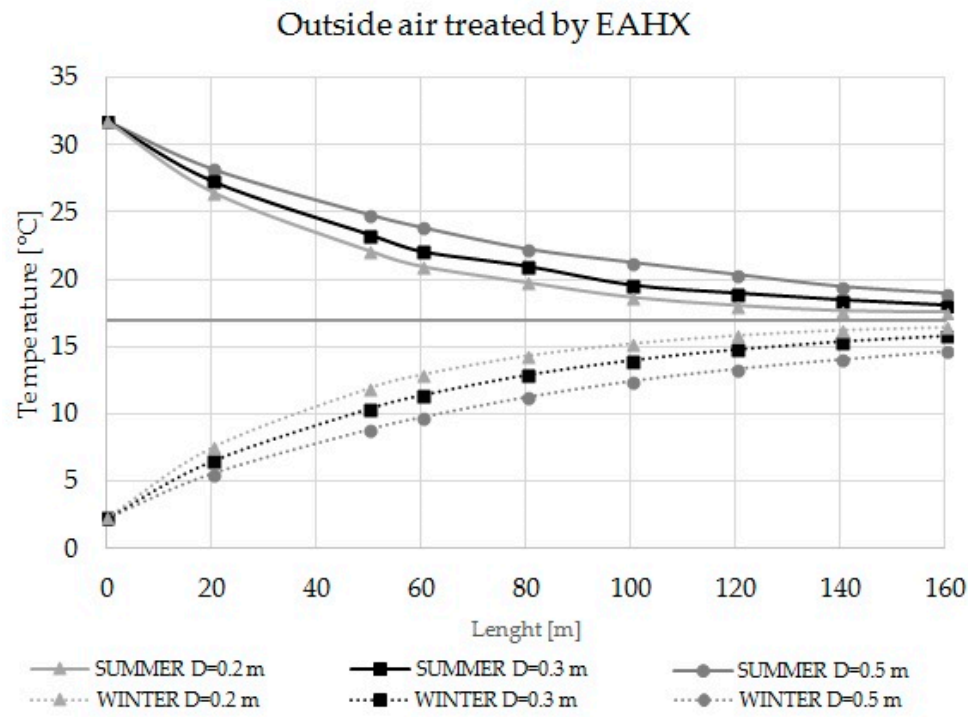

Figure 8. Air temperature at the outlet of the EAHX as a function of tube length for three different inner tube diameters in summer and winter.

Furthermore, it can be noted that decreasing the tube diameter the heat exchange becomes more efficient reaching a value of the outlet air temperature lower in summer and higher in winter. In particular, with the lower value of the diameter $(D=0.2 \mathrm{~m}$ corresponding to an inlet air velocity of $2.3 \mathrm{~m} / \mathrm{s}$ ) the absolute value of the temperature variation between the air at the inlet and at the outlet of the tube with a length of $100 \mathrm{~m}$ is equal to about $13^{\circ} \mathrm{C}$ for both the summer and winter season. Indeed, when decreasing the tube diameter, the air velocity increases enhancing the convection heat transfer coefficient.

It should be noted that for lengths greater than $100 \mathrm{~m}$ and $\mathrm{D}=0.2 \mathrm{~m}$, the air in the EAHX reaches a temperature lower than the dew point temperature, equal to $19.4^{\circ} \mathrm{C}$; therefore, the air is dehumidified and the outlet specific humidity $\omega$ decreases. In these cases, the mass flow rate of the condensed water $m_{c o}$ at the exit of EAHX is assessed, which is about $0.6 \mathrm{~g} \mathrm{~s}^{-1}$.

As far as the efficiency of the heat exchange is concerned, the Figure $9 a, b$ show how this both in summer and in winter reaches truly considerable values along the tube length. Specifically it can be seen in the Figure 9a that for the summer season, for lengths greater than $80 \mathrm{~m}$ the efficiency of the EAHX is well over 0.60, reaching values around 0.90 .

The uncertainty affecting this parameter was also provided and evaluated through the Moffat error propagation method [50].

The method prescribes that a generic property $Y$, indirectly calculated from measured or directly calculated independent parameters $x_{i}$, could be conceived as reported in Equation (22):

$$
Y=Y\left(x_{1}, x_{2}, \ldots, x_{n}\right),
$$

Therefore, $Y$ accuracy could be evaluated as a function of the accuracy associated to each $x i \mathrm{i}$, as reported in Equation (23):

$$
A_{y}=\left[\sum_{i=1}^{n}\left(\frac{\partial Y}{\partial x_{i}} A_{x i}\right)^{2}\right]^{1 / 2}
$$


Equation (23) clearly shows that this parameter depends on the error associated to: the air inlet, the air outlet and the ground temperature. The error associated to the inlet temperature is null since $T_{\text {inlet }}$ is provided as a design specification (an assumption) and not as a measured or calculated parameter. The maximum error (worst case) associated to the undisturbed ground temperature $\left(e_{T_{\text {ground }}}\right)$, given by the error propagation evaluated for the Kusuda relation (13), is $\pm 1^{\circ} \mathrm{C}$ [42].

To evaluate the error related to the outlet temperature $\left(e_{T_{\text {outlet }}}\right)$, since this parameter emerges from numerical computation, according to the guidelines reviewed by Freitas [51] for estimating the uncertainty deriving from CFD numerical simulations and following the 10 element policy statement for the control of numerical accuracy [52], the uncertainty was estimated as follows. Specifically, in simulations uncertainty can arise from:

- input uncertainty;

- model uncertainty;

- numerical uncertainty.

The error associated to first and the second points derives respectively from giving wrong input parameters and working with a not accurate code implementation. Supposing to have checked the correctness of the above points (input are the desired and the code is provided by a commercial software), the error associated to them is null.

The error associated to numerical uncertainty is a systematic error that cannot be reversed but only minimized, following the standard elements policy [52]. The procedure can briefly summarized in three different operations: documentation, verification and validation. Documentation and verification are preliminary steps to calculate the amount of the numerical error coming from validation. The validation embraces the estimation of the error deriving by the following contributions:

a. spatial grid convergence;

b. the choice of the most appropriate time-step to minimize time-discretization;

c. the iterative convergence of the non-linear solver;

d. the comparison with reliable experimental results.

The error values detected by points (a), (b) and (c) are (a) $\pm 0.01{ }^{\circ} \mathrm{C}$ (medium) and \pm 0.02 (maximum) (as declared in Section 3.2); (b) $\pm 0.001^{\circ} \mathrm{C}$ (medium and maximum); (c) $\pm 0.001{ }^{\circ} \mathrm{C}$ (medium), respectively.

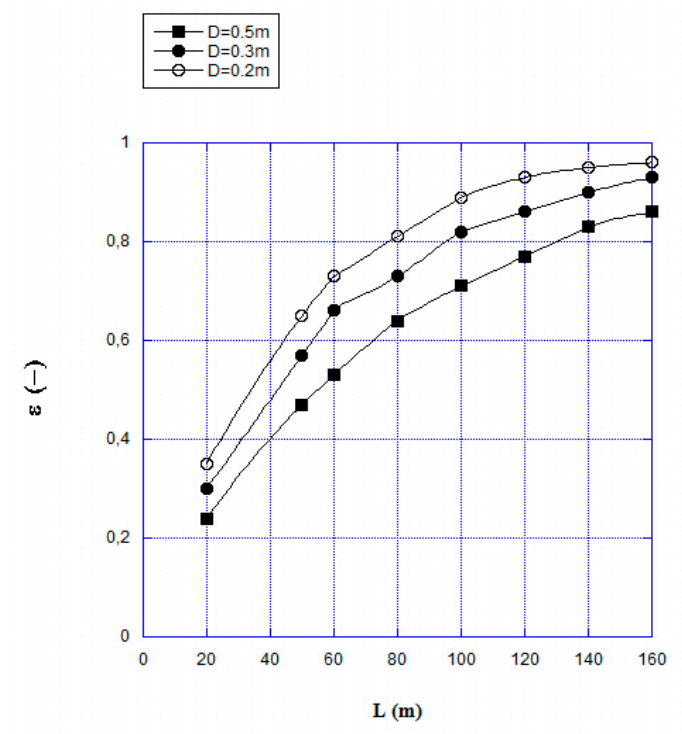

(a)

Figure 9. Cont. 


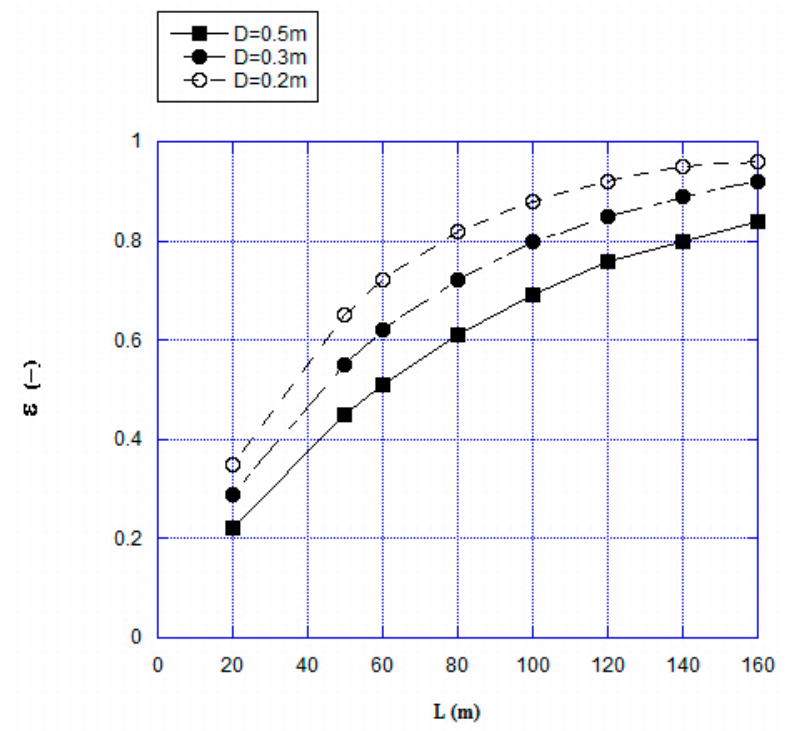

(b)

Figure 9. (a). Efficiency of the EAHX during summer season as a function of the tube length for three different inner tube diameters. (b). Efficiency of the EAHX during summer season as a function of the tube length for three different inner tube diameters.

To estimate the error values at point (d) deriving by the comparison with experimental results, as shown in Section 4.1, analyzing the validation with the experimental data provided by Hatraf et al. [48] and Khabbaz et al. [49], the maximum detected error value is $\pm 0.53{ }^{\circ} \mathrm{C}$. Indeed, the (a), (b), (c) error contributions were neglected and only the error values at point (d) were accounted. Therefore, basing on the above considerations, the uncertainty in evaluating the efficiency is $\pm 4 \%$ for tube lengths from $100 \mathrm{~m}$.

Similar results are found in the winter season (Figure 9b), where even here efficiencies reach values of around 0.90 . Both figures clearly show that a decrease of the tube diameter (corresponding to an increase of the air velocity) leads to an increase of the efficiency of the heat exchanger for each tube length.

Similar values are also found in literature $[20,31,53]$. In fact, the heat exchange efficiency in the EAHX, depending on the surrounding conditions (external air temperature, length and diameter of the tube), can reach values around 0.90-0.95. This is an important result also when considering the comparison between an air-to-air heat exchanger and an earth-to-air heat exchanger. In fact, the efficiency of the first technology settles around a value of 0.7 or less $[31,54,55]$.

In addition to having very high efficiency values, the EAHX is much more valuable from the point of view of the healthiness of the internal environment. In fact, when using the air-to-air heat exchangers (both the rotary and cross-flow type), the air entering the building to be conditioned can be can contaminated by Coronavirus or other viruses. On the contrary, the air passing through the EAHX pipes is external air extraneous to any contaminant present in the exhausted air.

\subsection{Reduction of the Thermal Power of the AHU Coils}

The considerable difference between the inlet and outlet temperature of the air from the EAHX (with a maximum absolute value of around $14.4{ }^{\circ} \mathrm{C}$ in both winter and summer season) leads to considerable reduction of the thermal power of the AHU coils. This reduction leads to many relevant advantages: energy savings and consequent reduction of polluting emissions, decrease of AHU cost.

In Figure 10 is reported the pre-heating coil power and the relative percentage of reduction by varying diameter and length of buried tubes during winter season. For a tube length of $140 \mathrm{~m}$, depending on the size of the diameter, during the winter season the power reduction on the pre-heating 
coil reaches $61-72 \%$. Equally considerable power reductions are obtained during the summer season when cooling coil is active: for example, considering the same length of $140 \mathrm{~m}$, this reduction reaches values between 39\% and 56\% (Figure 11).

Also the total power reduction on coils operating both in winter and summer are relevant (Figure 12a-c). When the yearly operation period of the AHU coupled to EAHX is considered, global power reductions of around $33 \%-43 \%$ are obtained considering a $100 \mathrm{~m}$ long tube. Increasing the length, these reductions are around $38 \%-49 \%$, usually higher than what would be obtained with an air-to-air heat exchanger (around 11\%, according to [33]). The greatest power reductions can be achieved considering the smallest diameter of $0.2 \mathrm{~m}$ (Figure 12c). For all the lengths considered, the reduction on power coils, when considering the entire year, is greatly affected by the length of the tube up to $80 \mathrm{~m}$, after which these reductions gradually settle at around $40-50 \%$.

It is important to specify that although there is an increase in electrical power of the AHU fan (due to the presence of the EAHX), it is about $5 \%-10 \%$ of this electrical power, and therefore the influence on the overall powers involved is negligible.

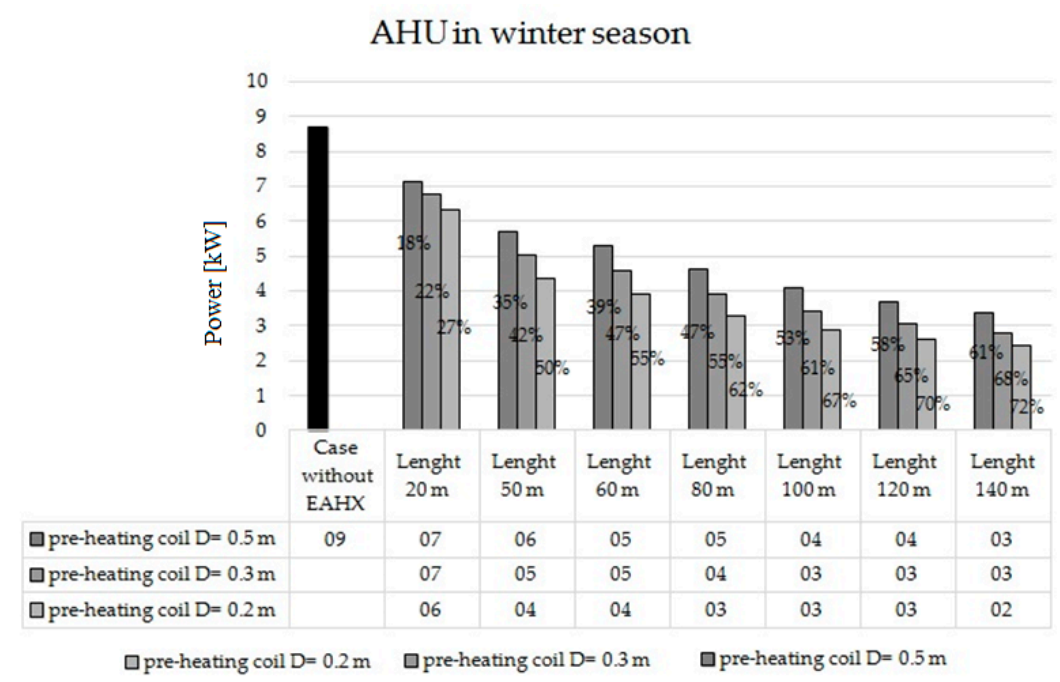

Figure 10. Power of pre-heating coil and relative percentage of reduction by varying diameter and length of buried tubes during winter.

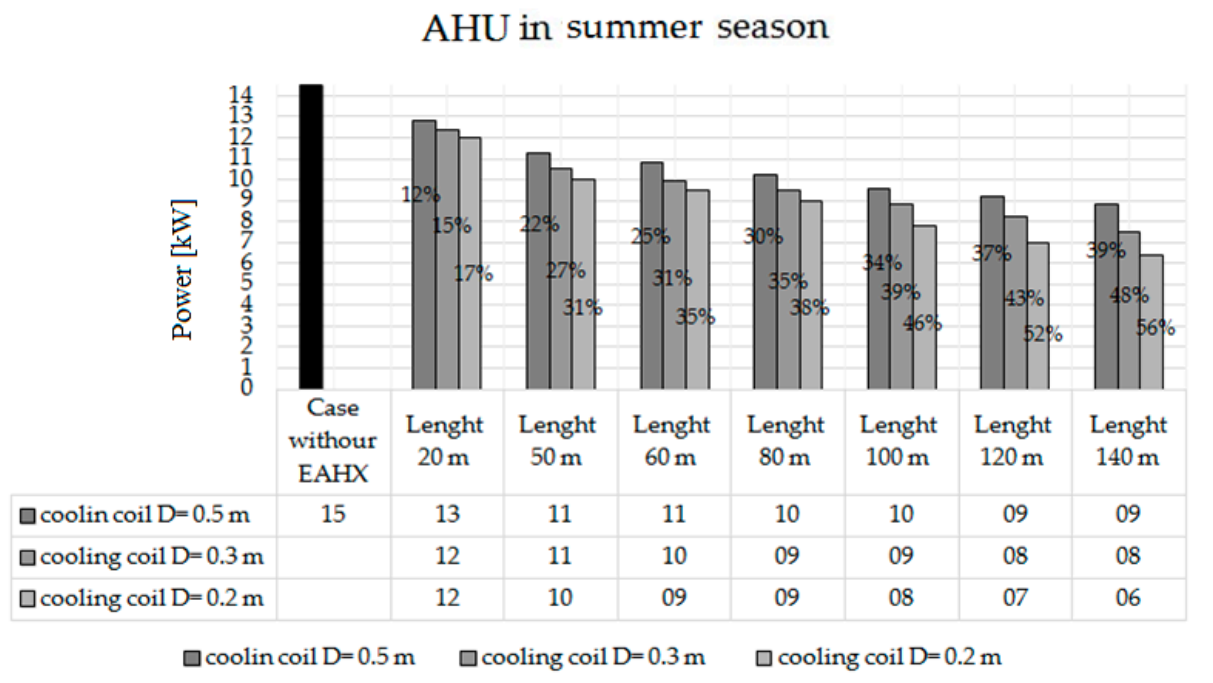

Figure 11. Power of cooling coil and relative percentage of reduction by varying diameter and length of buried tubes during summer season. 

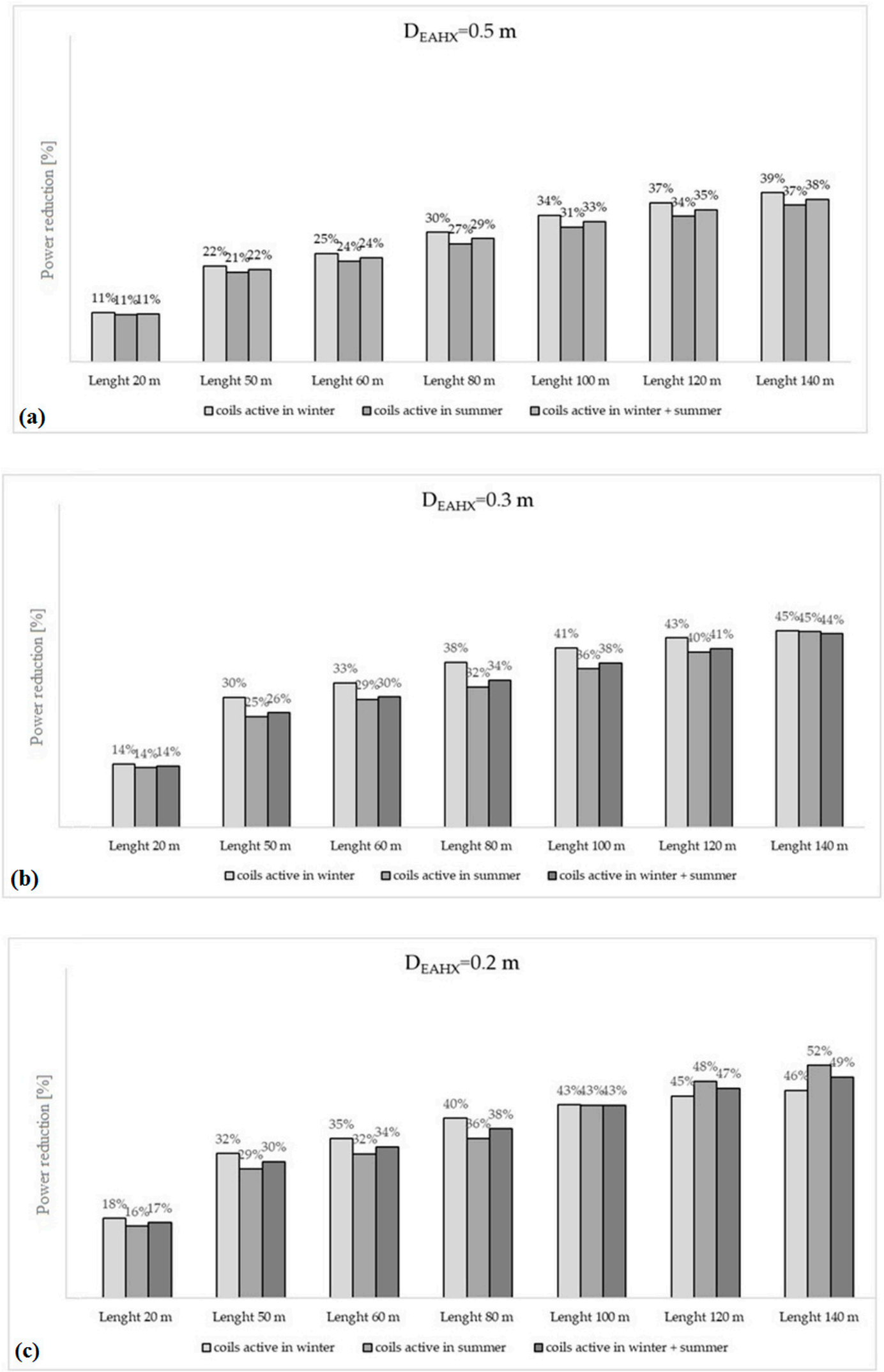

Figure 12. Percentage reduction of power AHU coils for different lengths of the EAHX and (a) $D_{\text {EAHX }}$ $=0.5 \mathrm{~m},(\mathbf{b}) \mathrm{D}_{\text {EAHX }}=0.3 \mathrm{~m},(\mathbf{c}) \mathrm{D}_{\mathrm{EAHX}}=0.2 \mathrm{~m}$. 


\section{Conclusions}

In this paper it is shown how the earth-to-air heat exchanger (EAHX) used upstream of an air-handling unit (AHU) inserted in an air-conditioning system can lead to considerable reductions on the power of the AHU coils (and consequently to significant energy savings). To this aim, a case study has been analysed, with reference to the air-conditioning system for an office building in a mild climate locality such as Naples (South Italy): a volumetric flow rate of $1300 \mathrm{~m}^{3} \mathrm{~h}^{-1}$ of external air is required for a satisfactory indoor air quality.

The EAHX has been extensively designed and two-dimensionally modeled, and then the analysis is solved with finite element method; the model has been then validated with experimental data. The main conclusions are herein reported.

- The heat exchange in the EAHX is very pronounced up to $80 \mathrm{~m}$ in length; for longer lengths, the air temperature gradually approaches an asymptotic value, in accordance with other investigations [31,40].

- With increasing length and reducing the diameter of the buried pipes from $0.5 \mathrm{~m}$ to $0.2 \mathrm{~m}$, considerable power reductions are obtained on the pre-heating coil $(60-70 \%)$ and on the cooling coil (40-55\%) of the AHU. In heating mode (winter) for lengths from $100 \mathrm{~m}$ upwards, the power reductions on the pre-heating coil are greater than $34 \%(D=0.5 \mathrm{~m})$ and reach up to $46 \%(\mathrm{D}=0.2 \mathrm{~m})$. Similar results are obtained during the summer season: starting from pipe lengths of $100 \mathrm{~m}$, reductions more than $31 \%$ are obtained for $\mathrm{D}=0.5 \mathrm{~m}$ and more than $43 \%$ for a $\mathrm{D}=0.2 \mathrm{~m}$. For all the diameters considered, the power reduction on AHU coils is globally between $33 \%$ and $49 \%$ for lengths starting from $100 \mathrm{~m}$.

- The heat exchange efficiency of the EAHX has also been evaluated and the values are very high, usually major compared to the more common air-to-air heat exchanger, reaching values up to 0.90 .

- These results lead to say that this system (EAHX for the geothermal pre-treatment of the air to be introduced into the AHU), is energetically very convenient. In fact, the energy consumption of a system can be expressed as the integral of the instantaneous power in a considered period, therefore if the maximum power is reduced, the maximum energy required by the system will also be reduced. For this reason, the paper has demonstrated that the HVAC system with the EAHX is competitive compared to the usual solution based on the air-to-air heat exchanger (which is also less suitable for the spread of Coronavirus and similar viruses).

Future work will include: (i) an analysis of the EAHX in different climatic zones; (ii) the analysis of the performance of the system in dynamic conditions, using daily climatic data; (iii) an analysis of the system optimization considering both thermal-energetic performances and an economic analysis.

Author Contributions: Conceptualization, D.D., F.E., A.G., C.M. and F.M.; Methodology, D.D., F.E., A.G., C.M. and F.M.; Validation, D.D., F.E., A.G., C.M. and F.M.; Formal Analysis, D.D., F.E., A.G., C.M. and F.M.; Investigation, D.D., F.E., A.G., C.M. and F.M.; Data Curation, D.D., F.E., A.G., C.M. and F.M.; Writing Original Draft Preparation, D.D., F.E., A.G., C.M. and F.M.; Writing Review \& Editing, D.D., F.E., A.G., C.M. and F.M.; Visualization, D.D., F.E., A.G., C.M. and F.M.; Supervision, D.D., F.E., A.G., C.M. and F.M.; Project Administration, A.G. and F.M. All authors have read and agreed to the published version of the manuscript.

Funding: This research received no external funding.

Conflicts of Interest: The authors declare no conflict of interest.

\section{Nomenclature}

Roman symbols

A amplitude of the temperature variation, ${ }^{\circ} \mathrm{C}$

$A_{i} \quad$ accuracy of the $\mathrm{i}^{\text {th }}$ directly calculated parameter

$A_{Y} \quad$ accuracy of the indirectly calculated parameter

AHU Air Handling Unit

C coefficient of K- $\hat{\varepsilon}$ model 


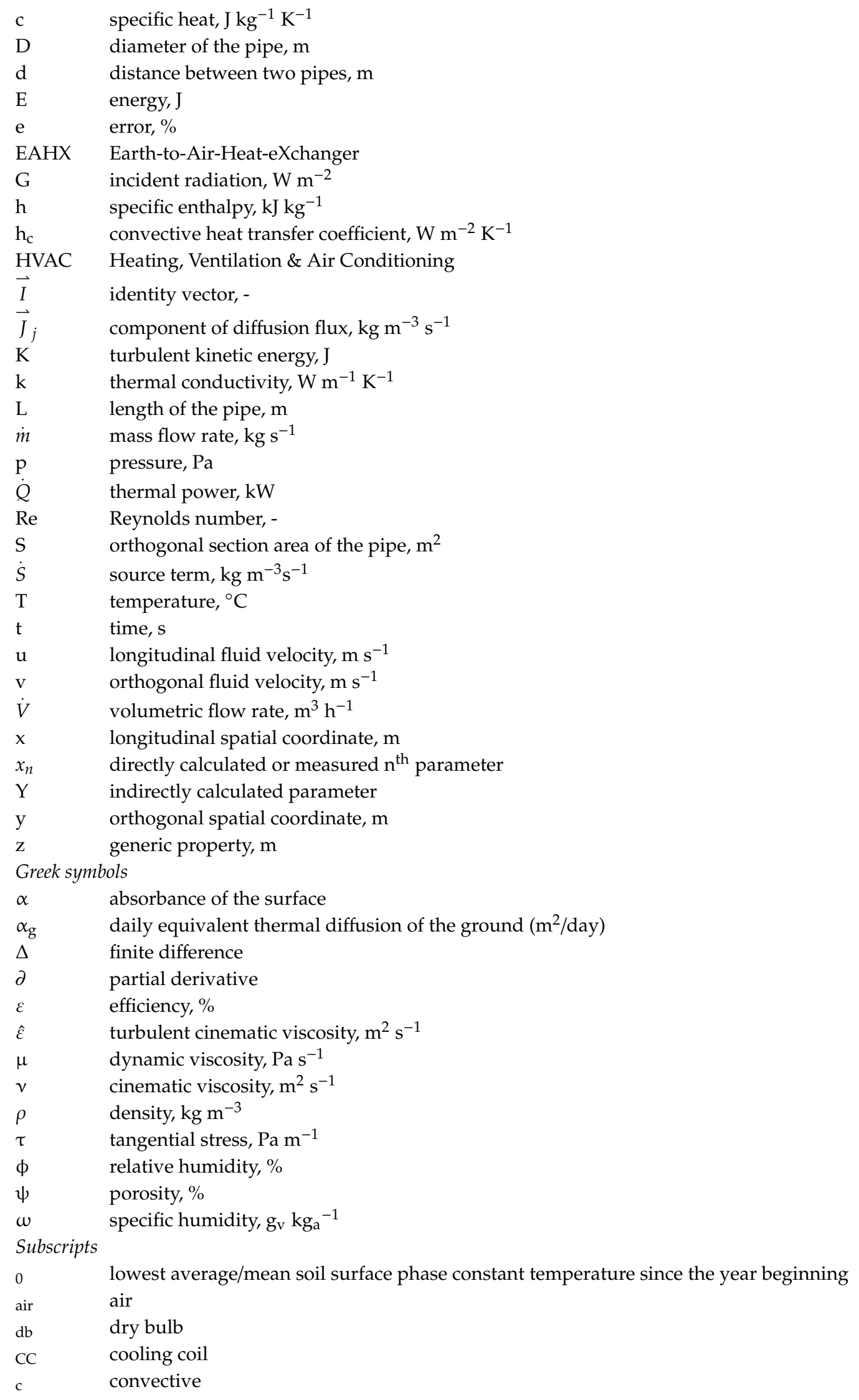




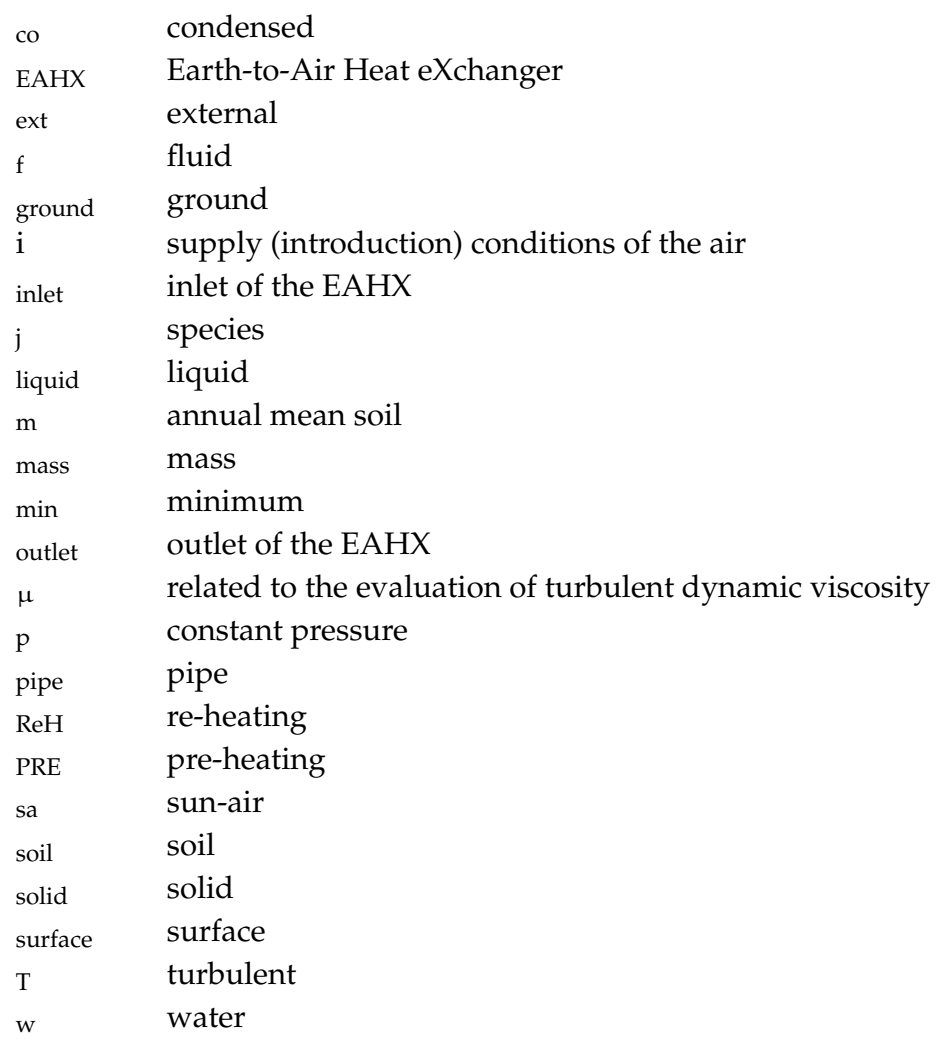

\section{References}

1. Soni, S.K.; Pandey, M.; Bartaria, V.N. Ground coupled heat exchangers: A review and applications. Renew. Sustain. Energy Rev. 2015, 47, 83-92. [CrossRef]

2. Sarbu, I.; Sebarchievici, C. General review of ground-source heat pump systems for heating and cooling of buildings. Energy Build. 2014, 70, 441-454. [CrossRef]

3. Le, T.H.; Chang, Y.; Park, D. Renewable and nonrenewable energy consumption, economic growth, and emissions: International evidence. Energy J. 2020, 41. [CrossRef]

4. Afridi, M.A.; Kehelwalatenna, S.; Naseem, I.; Tahir, M. Per capita income, trade openness, urbanization, energy consumption, and $\mathrm{CO}_{2}$ emissions: An empirical study on the SAARC Region. Environ. Sci. Pollut. Res. 2019, 26, 29978-29990. [CrossRef] [PubMed]

5. Al-Ghussain, L. Global warming: Review on driving forces and mitigation. Environ. Prog. Sustain. Energy 2019, 38, 13-21. [CrossRef]

6. World Bank Open Data-Electric Power Consumption (kWh per Capita). Available online: https://data. worldbank.org/indicator/EG.USE.ELEC.KH.PC (accessed on 17 March 2020).

7. Armeanu, D.Ş.; Gherghina, S..C.; Pasmangiu, G. Exploring the causal nexus between energy consumption, environmental pollution and economic growth: Empirical evidence from central and Eastern Europe. Energies 2019, 12, 3704. [CrossRef]

8. Franzén, I.; Nedar, L.; Andersson, M. Environmental comparison of energy solutions for heating and cooling. Sustainability 2019, 11, 7051.

9. Brown, D.R.; Stout, T.B.; Dirks, J.A.; Fernandez, N. The prospects of alternatives to vapor compression technology for space cooling and food refrigeration applications. Energy Eng. 2012, 109, 7-20. [CrossRef]

10. Brown, J.S.; Domanski, P.A. Review of alternative cooling technologies. Appl. Therm. Eng. 2014, 64, $252-262$. [CrossRef]

11. Goetzler, W.; Zogg, R.; Young, J.; Johnson, C. Alternatives to vapor-compression HVAC technology. ASHRAE J. 2014, 56, 12.

12. Rosiek, S.; Batlles, F.J. Renewable energy solutions for building cooling, heating and power system installed in an institutional building: Case study in southern Spain. Renew. Sustain. Energy Rev. 2013, 26, 147-168. [CrossRef] 
13. Moretti, E.; Bonamente, E.; Buratti, C.; Cotana, F. Development of innovative heating and cooling systems using renewable energy sources for non-residential buildings. Energies 2013, 6, 5114-5129. [CrossRef]

14. Pajak, L.; Tomaszewska, B.; Bujakowski, W.; Bielec, B.; Dendys, M. Review of the low-enthalpy lower cretaceous geothermal energy resources in Poland as an environmentally friendly source of heat for urban district heating systems. Energies 2020, 13, 1302.

15. Fridleifsson, I.B. Geothermal energy for the benefit of the people. Renew. Sustain. Energy Rev. 2001, 5, 299-312. [CrossRef]

16. Tester, J.W.; Anderson, B.J.; Batchelor, A.S.; Blackwell, D.D.; Di Pippo, R.; Drake, E.M.; Garnish, J.; Livesay, B.; Moore, M.C.; Nichols, K.; et al. The Future of Geothermal Energy; Massachusetts Institute of Technology: Cambridge, MA, USA, 2006; Volume 358.

17. Cadelano, G.; Cicolin, F.; Emmi, G.; Mezzasalma, G.; Poletto, D.; Galgaro, A.; Bernardi, A. Improving the energy efficiency, limiting costs and reducing $\mathrm{CO}_{2}$ emissions of a museum using geothermal energy and energy management policies. Energies 2019, 12, 3192. [CrossRef]

18. Trota, A.; Ferreira, P.; Gomes, L.; Cabral, J.; Kallberg, P. Power production estimates from geothermal resources by means of small-size compact climeon heat power converters: Case studies from Portugal (Sete Cidades, Azores and Longroiva Spa, Mainland). Energies 2019, 12, 2838. [CrossRef]

19. Bordoloi, N.; Sharma, A.; Nautiyal, H.; Goel, V. An intense review on the latest advancements of Earth Air Heat Exchangers. Renew. Sustain. Energy Rev. 2018, 89, 261-280. [CrossRef]

20. Zhao, Y.; Li, R.; Ji, C.; Huan, C.; Zhang, B. Parametric study and design of an earth-air heat exchanger using model experiment for memorial heating and cooling. Appl. Therm. Eng. 2019, 148, 838-845. [CrossRef]

21. Lin, J.; Nowamooz, H.; Braymand, S.; Wolff, P.; Fond, C. Impact of soil moisture on the long-term energy performance of an earth-air heat exchanger system. Renew. Energy 2020, 147, 2676-2687. [CrossRef]

22. Skotnicka-Siepsiak, A. Operation of a tube GAHE in Northeastern Poland in spring and summerA comparison of real-world data with mathematically modeled data. Energies 2020, 13, 1778. [CrossRef]

23. Díaz-Hernández, H.P.; Macias-Melo, E.V.; Aguilar-Castro, K.M.; Hernández-Pérez, I.; Xamán, J.; Serrano-Arellano, J.; López-Manrique, L.M. Experimental study of an earth to air heat exchanger (EAHE) for warm humid climatic conditions. Geothermics 2020, 84, 101741. [CrossRef]

24. Benrachi, N.; Ouzzane, M.; Smaili, A.; Lamarche, L.; Badache, M.; Maref, W. Numerical parametric study of a new earth-air heat exchanger configuration designed for hot and arid climates. Int. J. Green Energy 2020, 17, 115-126. [CrossRef]

25. Ascione, F.; D'Agostino, D.; Marino, M.; Minichiello, F. Earth-to-air heat exchanger for NZEB in Mediterranean climate. Renew. Energy 2016, 22, 553-563. [CrossRef]

26. Li, H.; Ni, L.; Yao, Y.; Sun, C. Annual performance experiments of an earth-air heat exchanger fresh air-handling unit in severe cold regions: Operation, economic and greenhouse gas emission analyses. Renew. Energy 2020, 146, 25-37. [CrossRef]

27. D'Agostino, D.; Marino, M.; Minichiello, F.; Russo, F. Two types of heat exchangers for office buildings in different European climates. Comput. Therm. Sci. Int. J. 2019, 11, 57-67. [CrossRef]

28. D'Agostino, D.; Marino, C.; Minichiello, F. The use of earth-to-air and air-to-air heat exchangers for different Italian climates. Int. J. Heat Technol. 2016, 34, S287-S294. [CrossRef]

29. D'Agostino, D.; Marino, C.; Minichiello, F. Earth-to-air versus air-to-air heat exchangers: A numerical study on the energetic, economic, and environmental performances for Italian office buildings. Heat Transf. Eng. 2019. [CrossRef]

30. Chiesa, G.; Zajch, A. Geo-climatic applicability of earth-to-air heat exchangers in North America. Energy Build. 2019, 202, 109332. [CrossRef]

31. Chiesa, G. EAHX-Earth-to-air heat exchanger: Simplified method and KPI for early building design phases. Build. Environ. 2018, 144, 142-158. [CrossRef]

32. Zeng, C.; Liu, S.; Shukla, A. A review on the air-to-air heat and mass exchanger technologies for building applications. Renew. Sustain. Energy Rev. 2017, 75, 753-774. [CrossRef]

33. Kalbasi, R.; Ruhani, B.; Rostami, S. Energetic analysis of an air handling unit combined with enthalpy air-to-air heat exchanger. J. Therm. Anal. Calorim. 2020, 139, 2881-2890. [CrossRef]

34. Chen, D.; Chen, H.W. Using the Köppen classification to quantify climate variation and change: An example for 1901-2010. Environ. Dev. 2013, 6, 69-79. [CrossRef] 
35. UNI 10339 Impianti aeraulici a fini di benessere. Generalità, classificazione, requisiti. Regole per la richiesta d'offerta, l'offerta, l'ordine e la fornitura. 1995. Available online: https://www.repertoriosalute.it/wp-content/ uploads/2015/03/UNI-10339-impianti-aeraulici.pdf (accessed on 15 April 2020). (In Italian).

36. Noorollahi, Y.; Saeidi, R.; Mohammadi, M.; Amiri, A.; Hosseinzadeh, M. The effects of ground heat exchanger parameters changes on geothermal heat pump performance-A review. Appl. Therm. Eng. 2018, 129, 1645-1658. [CrossRef]

37. Spitler, J.D.; Gehlin, S.E. Thermal response testing for ground source heat pump systems-An historical review. Renew. Sustain. Energy Rev. 2015, 50, 1125-1137. [CrossRef]

38. Peretti, C.; Zarrella, A.; De Carli, M.; Zecchin, R. The design and environmental evaluation of earth-to-air heat exchangers (EAHE). A literature review. Renew. Sustain. Energy Rev. 2013, 28, 107-116. [CrossRef]

39. Badescu, V. Simple and accurate model for the ground heat exchanger of a passive house. Renew. Energy 2007, 32, 845-855. [CrossRef]

40. Ascione, F.; Bellia, L.; Minichiello, F. Earth-to-air heat exchangers for Italian climates. Renew. Energy 2011, 36, 2177-2188. [CrossRef]

41. Mohammadi, B.; Pironneau, O. Analysis of the K-Epsilon Turbulence Model; MASSON: Paris, France, 1993.

42. Kusuda, T.; Achenbach, P.R. Earth Temperature and Thermal Diffusivity at Selected Stations in the United States (No. NBS-8972); National Bureau of Standards: Gaithersburg, MD, USA, 1965.

43. American Society of Heating, Refrigerating and Air-Conditioning Engineers (ASHRAE). ASHRAE Handbook Fundamentals, SI ed.; ASHRAE: Atlanta, GA, USA, 2017.

44. D.P.R. 26 agosto 1993. n. 412, Regolamento Recante norme per la Progettazione, L'installazione, L'esercizio e la Manutenzione Degli Impianti Termici Degli Edifici, in Attuazione Dell'art. 4, Comma 4, della L. 9 Gennaio 1991, n. 10; President of the Italian Republic: Roma, Italy, 1993. (In Italian)

45. Cavazza, L. Fisica del Terreno Agrario; UTET: Torino, Italy, 1981. (In Italian)

46. Verein Deutscher Ingenieure (VDI). VDI 4640 Thermal Use of the Underground; VDI: Düsseldorf, Germany, 2010.

47. Bortoloni, M.; Bottarelli, M. Modeling a novel shallow ground heat exchanger. In Proceedings of the 2012 COMSOL Conference, Milan, Italy, 10-12 October 2012.

48. Hatraf, N.; Chabane, F.; Brima, A.; Moummi, N.; Moummi, A. Parametric study of to design an earth to air heat exchanger with experimental validation. Eng. J. 2014, 18, 41-54. [CrossRef]

49. Khabbaz, M.; Benhamou, B.; Limam, K.; Hollmuller, P.; Hamdi, H.; Bennouna, A. Experimental and numerical study of an earth-to-air heat exchanger for air cooling in a residential building in hot semi-arid climate. Energy Build. 2016, 125, 109-121. [CrossRef]

50. Moffat, R.J. Describing the uncertainties in experimental results. Exp. Therm. Fluid Sci. 1988, 1, 3-17. [CrossRef]

51. Freitas, C.J. The issue of numerical uncertainty. Appl. Math. Model. 2002, 26, 237-248. [CrossRef]

52. Haworth, D.C.; El Tahry, S.H.; Huebler, M.S. A global approach to error estimation and physical diagnostics in multidimensional computational fluid dynamics. Int. J. Numer. Methods Fluids 1993, 17, 75-97. [CrossRef]

53. Chiesa, G. Climate-potential of earth-to-air heat exchangers. Energy Procedia 2017, 122, 517-522. [CrossRef]

54. Qiu, S.; Li, S.; Wang, F.; Wen, Y.; Li, Z.; Li, Z.; Guo, J. An energy exchange efficiency prediction approach based on multivariate polynomial regression for membrane-based air-to-air energy recovery ventilator core. Build. Environ. 2019, 149, 490-500. [CrossRef]

55. Rojas, G.; Pfluger, R.; Feis, W. Cascade ventilation-Air exchange efficiency in living rooms without separate supply air. Energy Build. 2015, 100, 27-33. [CrossRef]

(C) 2020 by the authors. Licensee MDPI, Basel, Switzerland. This article is an open access article distributed under the terms and conditions of the Creative Commons Attribution (CC BY) license (http://creativecommons.org/licenses/by/4.0/). 